\title{
A review of efficiency of nitrogen utilisation in lactating dairy cows and its relationship with environmental pollution ${ }^{*}$
}

\author{
A.R. Castillo ${ }^{1}$, E. Kebreab ${ }^{2}$, D.E. Beever and J. France \\ The University of Reading, Centre for Dairy Research, Department of Agriculture \\ Earley Gate, P.O.Box 236, Reading RG6 6AT, United Kingdom
}

(Received 11 June 1999; accepted 13 January 2000)

\begin{abstract}
The objective of this paper is to review the literature concerning nitrogen utilisation in lactating dairy cows with an emphasis on their contribution to environmental pollution. Nitrogen, as oxides or ammonia, is one of the green houses gases contributing to air pollution and through leaching to rivers and ground water resources. A quantitative analysis of the contribution of dairy cows to pollution at the farm level is given and the effect of different types of carbohydrate and protein supplementation discussed. The rclationship between nitrogen intake and nitrogen balance was investigated using data from 580 dairy cows and 90 treatments published in the literature. Regression analysis described the relationships between nitrogen intake and output in faeces, urine and milk. Inefficient utilisation of nitrogen by dairy cows indicates that about $72 \%$ of consumed nitrogen is excreted in faeces and urine. There were positive linear relationships between nitrogen intake and output in faeces, urine and milk up to an intake of $400 \mathrm{~g} \mathrm{~N} / \mathrm{d}$. However, above $400 \mathrm{~g} \mathrm{~N} / \mathrm{d}$, excretion in urine increased exponentially while the rate of increase in nitrogen excretion in faeces and milk declined linearly. To reduce nitrogen pollution, it is recommended to decrease the amount of crude protein in the total diet to approximately $150 \mathrm{~g} / \mathrm{kg}$ DM which compared with levels of $200 \mathrm{~g} / \mathrm{crude}$ protein $/ \mathrm{kg} \mathrm{DM}$ consumption can reduce annual nitrogen excretion in faeces by $21 \%$ and more importantly in urine by $66 \%$. Management practices with respect to silage making and the choice of supplements need to be considered with the aim of reducing total nitrogen in excreta and if possible shifting nitrogen excretion from urine to faeces.
\end{abstract}

KEY WORDS: nitrogen pollution, dairy cow, nitrogen balance, model

\footnotetext{
' Present address: EEA Rafaela INTA Casilla de correo 22, (2300) Rafaela, Santa Fe, Argentina

2 Corresponding author

* Supported by the MAFF Environmental Protection Division (UK)
} 


\section{INTRODUCTION}

Nitrogen utilisation in dairy cows

There are important biological and economical reasons to reduce $\mathrm{N}$ losses and improve its utilisation in dairy cattle. One of the major problems of grazed and conserved grasses and legumes is the reduced efficiency of protein utilisation (Beever and Reynolds, 1994). It is accepted that this problem can be overcome with an increased use of protein supplements, but feeding cows with more protein than needed is wasteful, resulting in elevated feed costs, reduced profits (Roffler and Thacker, 1983; Kalscheur et al., 1999) and further reductions in the efficiency of $\mathrm{N}$ utilisation (Peyraud et al., 1995). Furthermore, such practices do not always lead to improved lactational performance (Ulyatt, 1997; Santos et al., 1998). Additionally, high intakes of rumen degradable protein are often associated with possible changes in milk composition and this may affect industrial milk quality (e.g. Horne and Muir, 1990; DePeters and Ferguson, 1992; Hermansen et al., 1999).

Excessive $\mathrm{N}$ intake, especially as rumen degradable $\mathrm{N}$ has been also associated with reduced reproductive performance in dairy cows and low efficiency of body weight gain in steers (e.g. Hibbitt, 1988; Ferguson and Chalupa, 1989; Broderick, 1992; Butler, 1997). Finally, and probably the most important reason to improve $\mathrm{N}$ utilisation in dairy cattle is in relation to environmental concern. In the UK and other countries in the EU, dairy farms are regarded as potentially major sources of N pollution (e.g. Korevaar, 1992; Simon et al., 1994; Weissbach and Ernst, 1994; Peel et al., 1997).

\section{Contribution to nitrogen pollution in the environment}

The agricultural sector is responsible for about $40 \%$ of the anthropogenic nitrous oxide emissions in Europe (Morard, 1999). In the last few decades, the relatively low price of $\mathrm{N}$ fertilisers, leading to high rates of $\mathrm{N}$ application in agriculture and associated intensive animal production systems have created an important $\mathrm{N}$ imbalance in nature, which has significantly contributed to the pollution of the environment (Viets and Hageman, 1971). Dairy farming is responsible for more losses of $\mathrm{N}$ in faeces and urine than any other ruminant and nonruminant systems of production (MAFF Environment, 1994), and is known to contribute to both atmospheric and hydrospheric pollution (Tamminga, 1992).

In the atmosphere, inputs of ammonia have increased by more than $50 \%$ since 1950. It is recognised that intensification of animal production systems, with 
higher number of animals per farm has been one of the major causes of this change (Jarvis, 1994; Asman et al., 1998). Muck and Steenhuis (1982) determined the concentration of urea in urine to be the main factor involved in the volatilisation of ammonia. However, the quantitative relationships between levels and types of dairy cow nutrition, urinary $\mathrm{N}$ excretion and ammonia volatilisation in grazing and/or housed dairy cattle has not been fully established (Smits et al., 1995; Asman et al., 1998). There is, however, experimental evidence that appropriate nutritional management of dairy cows may substantially reduce ammonia emissions (Smits et al., 1995). Other workers have also suggested ways of reducing ammonia emissions in agriculture (Korevaar and den Boer, 1990; Tamminga, 1992; Weissbach and Ernst, 1994; Smits et al., 1995; Jarvis et al., 1996; Tamminga and Verstegen, 1996; Asman et al., 1998; Ledgard et al., 1998). Those specifically related to nutrition and $\mathrm{N}$ utilisation in dairy cows were (a) reducing $\mathrm{N}$ content of animal feeds by adjusting animals requirements to obtain optimal nutrition for each physiological stage of development of the animal, (b) decreased labile rumen $\mathrm{N}$ levels by reducing the ruminal degradation of dietary protein and (c) improved energy:protein synchrony in the rumen in order to improve the efficiency of capture of ruminally degraded $\mathrm{N}$ through microbial protein synthesis.

With respect to hydrospheric pollution, it was recently estimated that surplus $\mathrm{N}$ fertiliser leaching to groundwater as nitrates in grazing systems amounted to approximately $40 \%$ of the quantity applied (Ledgard et al., 1998). Nitrate concentration in water is a concern in many areas of Europe. According to the European Union (EU) directive concerning the protection of waters against pollution caused by nitrates from agricultural sources (Council Directive 91/676/EEC), the maximum allowable concentration should be less than $50 \mathrm{mg}$ nitrate/L of drinking water. However, this limit has been exceeded in many UK watercourses over the last few years (Jarvis, 1994).

\section{Objectives}

This review focuses on $\mathrm{N}$ utilisation in dairy cattle, the effects of protein and energy supplementation and their synchrony on $\mathrm{N}$ utilisation and lactational performance, and specifically the contribution of dairy cows fed high quality forage diets to $\mathrm{N}$ pollution. Published information on $\mathrm{N}$ balance experiments from 580 lactating dairy cows has been collated and the effect of $\mathrm{N}$ intake, subsequent $\mathrm{N}$ partition to milk, urine, faeces and the efficiency of $\mathrm{N}$ utilisation in individual cows and at farm level has been analysed to provide recommendations for reducing $\mathrm{N}$ excretions. 


\section{NITROGEN UTILISATION IN DAIRY COWS}

\section{Effect of protein supplementation on lactational performance}

In UK, where grass silage forms the principal forage for dairy cows, it is normal practice to supplement with dairy concentrates containing up to $200 \mathrm{~g} \mathrm{CP} / \mathrm{kg} \mathrm{DM}$ (Sutton et al., 1994). There has been much interest in the provision of slowly degradable protein sources to improve amino acid availability in high yielding dairy cows (fish meal or formaldehyde treated soya), by increasing duodenal protein supply as rumen undegradable dietary protein (Beever, 1993). However, lactational responses to rumen undegradable protein supplementation on high quality forage diets have been quite variable (Ulyatt, 1997; Santos et al., 1998).

A large number of studies were compiled in a review on the use of rumen undegradable protein supplements and protein nutrition of lactating dairy cows by Santos et al. (1998). The main conclusion was that increased rumen undegradable protein in dairy cow diets, which often resulted in a decreased supply of rumen degradable protein and a change in the profile of amino acids absorbed, does not consistently improve lactational performance. Alderman and Blake (1995) also observed that increasing the proportion of rumen undegradable protein in the dietary $\mathrm{CP}$ fraction for very high yielding cows may result in an inadequate supply of effective rumen degradable protein to the rumen microbes.

Santos et al. (1998) also indicated that fish meal and treated soyabean meal were the sources of rumen undegradable protein that gave the most positive production responses. Broderick (1992) concluded that fish meal gives better responses compared with soyabean meal in early lactation and provides an excellent source of amino acids to the animal. However, fish meal inclusion may affect rumen metabolism (Beever and Gill, 1990) and in some situations has been shown to increase the flow of both microbial and ruminally undegraded dietary protein to the duodenum (Dawson et al., 1988). It is also apparent that not all fish meal sources behave similarly within the rumen, which may be associated with the variable ash and lipids found in some of these products (Beever, 1993).

A more consistent response to increased rumen degradable rather than undegradable protein has been observed on grass and lucerne silage based diets. Reductions in rumen degradable protein supply reduced microbial protein flow from the rumen, which was presumably due to the lack of supply of amino acids and peptides to the rumen microbes (Hoover and Stokes, 1991; Dijkstra et al., 1998). Substitution of part of the rumen degradable protein of grass silage (Sutton et al., 1994, 1996) or lucerne silage (Cadorniga and Sutter, 1993) with a high quality source of rumen degradable protein, tended to improve total DM intake and milk yield with only marginal effects on milk constituent concentration, suggesting that 
protein, not energy, could be the first limiting nutrient for milk yield on these forages (Dhiman et al., 1993; Dhiman and Satter, 1993; Aston et al., 1994).

Under grazing conditions, the evidence suggests that a production response to rumen undegradable protein will be obtained only if the animal is truly limited in protein and/or amino acids supply (Beever and Siddons, 1986; Ulyatt, 1997; Hongerhold and Muller, 1998). Responses to supplementation of rumen undegradable protein under grazing are not clear. Dhiman et al. (1997) working with high yielding dairy cows supplemented with high maize and roasted soyabeans on a high quality pasture, concluded that the lack of a milk production response to the feeding of a high quality source of rumen undegradable protein was surprising. The authors also indicated that grazed grass was a more effective source of protein than ensiled grass or legume forages, which may contain $50 \%$ or more of the CP in non-protein $\mathrm{N}$ forms, as discussed by Beever and Siddons (1986) and Beever and Reynolds (1994).

\section{Effect of carbohydrate composition in the supplement on lactational performance}

Many experiments have been undertaken to compare the effect of different concentrates with respect to energy or protein content and type on animal performance. A mixture of high quality energy and protein in the concentrate has been shown to increase total dry matter intake and improve lactational performance on grass silage based diets (Sutton et al., 1994; Keady and Murphy, 1998), with similar responses noted for diets based on lucerne silage (Dhiman et al., 1993; Dhiman and Satter, 1993) and grazed temperate pastures (Leaver, 1985). There appears to be two key aspects in the response pattern to concentrate feeds in relatively well balanced diets, namely: (1) the availability of high quality forages with good intake characteristics, especially with respect to silages (Sutton et al., 1996) and (2) the quality of the source of energy and protein in the concentrate. However, Thomas (1984) cited some examples from the literature in which diets supplying similar amounts of $\mathrm{ME}$ in the concentrate but differing in carbohydrate composition gave rise to different levels of milk protein production.

The responses to different concentrates at the same level of supplementation are not fully established in dairy cows. Production performance is a major indicator of whether manipulating the site of carbohydrate or protein digestion is a useful technique. Several reviews have compared the effect of starch and/or rumen undegradable protein supplementation on animal performance (Nocek and Tamminga, 1991; Huntington, 1997; Reynolds et al., 1997; Santos et al., 1998). High energy intake appeared to be the main reason for increased production, but in cows at peak lactation fed on a diet containing $180 \mathrm{~g} \mathrm{CP} / \mathrm{kg} \mathrm{DM}$, duodenal starch infusion had no effect on milk protein production or milk yield, which does not support the concept that increased glucose supply from post-ruminal starch digestion 
will increase milk protein concentration (Reynolds et al., 1996). Taking a number of studies into consideration, Nocek and Tamminga (1991) observed that, although it was possible to shift the site of starch digestion, it was difficult to identify any specific effects of different starch sources, concluding that there was no clear evidence that post-ruminal starch digestion enhances milk yield or changes milk composition which was in agreement with Reynolds et al. (1996). Huntington (1997), stimulated starch digestion and glucose uptake by the small intestine, but concluded that the amount of glucose used by the visceral tissues of ruminants consuming high grain diets is equal to or often greater than the amount of glucose absorbed from the small intestine thus providing no net gains to the animal. It is generally accepted that rumen propionate or glucose directly absorbed by the intestines stimulates an insulin response, which in turn increases the uptake of glucose by non-mammary tissues. In such situations, mammary glucose uptake and hence milk yield are relatively unaffected (Nocek and Tamminga, 1991; Huntington, 1997; Reynolds et al., 1997).

Replacement of cereal starch by various soluble carbohydrate sources, including lactose, whey, molasses and soluble condensed molasses, has been found to prevent or reduce the depression in milk fat caused by low roughage diets. Sutton (1989) concluded that the responses to soluble carbohydrates are often quite variable even with diets containing normal amounts of forage. In cows fed a 70:30 ratio of concentrate to grass silage diet, with the concentrate based on barley or molassed sugar beet feed, total energy output was unaffected. However, the cows fed on the barley based concentrate partitioned more energy to milk with increased energy mobilisation, compared with those on molassed sugar beet feed (Beever et al., 1989). Evaluating different levels of molasses in dairy cows rations, based principally on grass silage, Yan et al. (1997) found that high concentrations of molasses (250 $\mathrm{g} / \mathrm{kg} \mathrm{DM})$ supplemented with a urea/soyabean meal mix increased milk production, but both fat and protein concentrations decreased when the protein supplements were replaced by unprotected tallow. These studies concluded that lactating dairy cows on diets balanced in protein could be given molasses at an inclusion rate in the total ration of up to $250 \mathrm{~g} / \mathrm{kg}$ DM without adverse effects on milk production or health. With respect to other non-starch soluble carbohydrates, Belibasakis and Tsirgogianni (1996), replaced dried beet pulp (15\% total DMI) and ground maize ( $8 \%$ total DMI) with citrus pulp and found a significant increase in milk fat content and yield but no effect on the production of milk or other milk components, in agreement with Sutton (1989). Santos et al. (1999) however, working with higher yielding dairy cows (over $35 \mathrm{~kg}$ milk/d) found an improved performance when high quality rumen undegradable protein and high rumen degradable starch from steam-processed grains were fed with a basal lucerne diet.

The effects of fibre in compound feeds on the performance of dairy cows have been studied under indoor and grazing conditions (Steg et al.,1985; Meijs, 1986; Valk et al., 1990; Aston et al., 1994; Gonda et al., 1996). In general, when the 
supplement included an increased proportion of fibre rather than non-structural carbohydrates, increased milk fat and decreased milk protein concentrations, with or without changes in total milk production, have been noted.

\section{Synchronising energy-protein in the rumen}

The efficient growth of rumen micro-organisms and the consequent optimisation of microbial protein supply to the animal requires the simultaneous availability of substrates, namely energy (carbohydrate) and protein (Dijkstra et al., 1998). Improvements in the efficiency of capture of rumen degradable $\mathrm{N}$ by the microbes would reduce the need for expensive rumen undegradable protein sources and also reduce the excretion of urinary $\mathrm{N}$ (Sinclair et al., 1993).

Important advances have been made in improving the energy:protein ratio in the rumen and defining animal requirements. These systems are based on the rumen degradable and undegradable fractions of dietary protein (e.g. INRA, 1978, 1988; ARC, 1980, 1984; NRC, 1989). Moreover, calculations for energy and protein requirements now include ruminal rates of degradation of dietary protein (AFRC, 1993) whilst the rate of degradation of different chemical components of the dietary carbohydrate and protein fractions is recognised in some systems (Fox et al., 1992).

Attempts have been made to improve energy and protein utilisation, by consideration of the relative rates of ruminal degradation of these nutritional entities. An index was defined by Sinclair et al. (1993), which described the degree of synchrony between hourly supply of $\mathrm{N}$ and organic matter in the rumen, based on in situ degradability data. Matching or synchronising energy-protein supply in the diet in order to improve $\mathrm{N}$ utilisation in the rumen, has been the aim of several studies with dairy cows (Herrera-Saldana and Huber, 1989; Herrera-Saldana et al., 1990; Kolver et al., 1998; Shabi et al., 1998).

Some positive results have been achieved in terms of rumen microbial $\mathrm{N}$ production (Sinclair et al., 1993, 1995) or improved milk production and composition (Herrera-Saldana et al., 1989; Shabi et al., 1998). However, other workers have reported only marginal or often no effects of synchronised diets on milk production and composition (Henderson et al., 1998; Kolver et al., 1998; Witt et al., 1998, 1999). This lack of response may be due to the involvement of other factors, whilst current representations of synchronisation might not have been sufficient to describe the processes of nutrient assimilation in the rumen.

Working under controlled in vitro conditions, Newbold and Rust (1992) showed that rumen bacteria were unaffected by synchronisation of nutrient supply. The rumen bacterial population was estimated to be greater at 5 to $8 \mathrm{~h}$ postincubation for synchronised compared with asynchronised treatments, using glucose and urea as substrates, but after $12 \mathrm{~h}$ no differences between treatments, 
leading the authors to conclude that bacterial growth recovered quickly from transient restrictions due to deficits of nitrogen. These results agree with Henning et al. (1993) who concluded that merely improving the degree of synchronisation between rates of energy and $\mathrm{N}$ release in the rumen did not give predictable increases in microbial yield.

Ruminal degradation of dietary components depends not only on the chemical nature of each feed and different physical and/or chemical treatments, but also on the competition between rates of digestion and passage (Mertens and Ely, 1979; ARC, 1984; Nocek and Tamminga, 1991; Van Soest et al., 1991), providing an important range of possibilities for each feed. In a report by the Technical Committee on Responses to Nutrients (AFRC, 1999), the authors indicated that it is important to recognise that further modifications to the systems of feed characterisation will need to accommodate new approaches to the prediction of animal response. For fibrous carbohydrates, starch and protein, it seems likely that current chemical descriptions of feeds will prove inadequate for predictive purposes, since estimates of likely rates of degradation of each nutrient fraction when in contact with rumen bacteria are required by all current models.

\section{NITROGEN BALANCE STUDIES AND ANALYSIS}

\section{Measurement of nitrogen balance}

Nitrogen balance studies have been extensively carried out for many years in order to investigate protein metabolism in human and monogastric animals (Spanghero and Kowalski, 1997). In dairy cattle, these approaches were also used (e.g. Susmel et al., 1995; Gonda et al., 1996), to evaluate feedstuffs (e.g. Keady et al., 1998; Sutton et al., 1998a; Wright et al., 1998), and study ways to reduce N excretion (e.g. Peyraud et al., 1995; Bockmann et al., 1996). Nowadays, $\mathrm{N}$ balances are used to define animal requirements whilst considering environmental problems in relation to animal production (Kristensen et al., 1998).

A complete $\mathrm{N}$ balance is required to examine the partition of total $\mathrm{N}$ intake as $\mathrm{N}$ output in faeces, milk, urine and the foetus, and if body weight change occurs, any $\mathrm{N}$ retained or mobilised must also be considered (Spanghero and Kowalski, 1997; Kristensen et al., 1998). Bockmann et al. (1996) and Kristensen et al. (1998) found differences in the extent of $\mathrm{N}$ excretion with cows in different phases of lactation. There is evidence that the increase in feed intake that occurs in early lactation could affect determinations and may underestimate $\mathrm{N}$ intake in cows after calving. Moreover, when cows are pregnant, $\mathrm{N}$ retention by the foetus and associated structures becomes quantitatively important in the last two months of lactation or the third trimester of gestation (ARC, 1980). As a result, it is recommended to use 
dairy cows at similar stages of lactation, with normal intake capacities and when less than 6 months pregnant.

Sources of error in $\mathrm{N}$ balance trials were analysed by Spanghero and Kowalski (1997). According to their results, underestimation of faecal $\mathrm{N}$ by incomplete collection of material or volatile losses of ammonia during collection or subsequent drying of the samples could be important. The authors evaluated the effects of leaving faeces in the cowshed for different period and recommended collecting faeces at least every $24 \mathrm{~h}$ and to determine the $\mathrm{N}$ content in wet samples in order to minimise ammonia losses. A second cause of error may be volatile $\mathrm{N}$ losses during urine collection and a strong acid $\left(\mathrm{HCl}\right.$ or $\mathrm{H}_{2} \mathrm{SO}_{4}$ ) must be used to prevent such losses. From a number of different trials with dairy cows an average $\mathrm{N}$ retention of almost $40 \mathrm{~g} / \mathrm{d}$ was calculated, which converted to total lean tissue, suggests a gain of approximately $1 \mathrm{~kg} / \mathrm{d}$ (by adopting a coefficient of 6.25 , assuming a body protein content of $16 \%$ and a ratio of $1: 3$ protein:water in the body). This estimate appears to be too high, especially for high yielding dairy cows in early lactation. Scurf and dermal losses are other sources of $\mathrm{N}$ output, but are difficult to measure and can be considered relatively small when compared to other losses. Spanghero and Kowalski (1997) concluded that underestimation of $\mathrm{N}$ losses in balance studies are important, and recommended a number of approaches to improve $\mathrm{N}$ metabolism data, specifically to avoid over-estimations of $\mathrm{N}$ retention, which have often been reported.

\section{Partition of dietary nitrogen to faeces, urine and milk nitrogen output}

Nitrogen excretion in faeces and urine represent a significant proportion of total $\mathrm{N}$ intake, and may approach $80 \%$ of daily consumption depending on different feed sources (Bruchem et al., 1991). Nitrogen excreted in faeces by dairy cows is reported to be rather constant in proportion to DM intake, about $7.5 \mathrm{~g} / \mathrm{kg}$ DM ingested according to Peyraud et al. (1995) or $0.6 \%$ of the dietary DM intake (Van Soest, 1994). Faeces are composed of undigested feed N, undigested microbial $\mathrm{N}$ and endogenous $\mathrm{N}$ (Tamminga, 1992), but reduction in faecal $\mathrm{N}$ excretion did not appear to be a promising way to achieve any substantial reduction in $\mathrm{N}$ loss from the animal (Tamminga, 1992; Van Soest, 1994). This is due to the true digestibility of feed protein in most dairy cow rations being high, whilst digestibility of microbial protein is also high, so suggesting little improvement in digestibility is possible (Tamminga, 1992).

Urinary $N$ excretion on the other hand, appears to be a more promising means by which $\mathrm{N}$ output in dairy cattle can be managed. Various routes contribute to urinary $\mathrm{N}$ output including ruminal and metabolic losses (Tamminga, 1992). Moreover, increases in dietary protein or $\mathrm{N}$ intake generally lead to substantial increases in urinary loss (Van Soest, 1994) with almost all $\mathrm{N}$ ingested in excess of animal requirement excreted in urine (Peyraud et al., 1995; Bockmann et al., 1996). 
In many countries, high quality forages such as grass silage and lucerne silage are the cheaper components in dairy cow diets and thus represent the main source of $\mathrm{N}$ for dairy cattle. However, one of the major problems with these forages is the reduced efficiency of $\mathrm{N}$ utilisation. Different solutions have been considered, including supplementation with low rumen-degradable protein, although this is not highly recommended because it could indirectly stimulate $\mathrm{N}$ excretion (Peyraud et al., 1995). Increasing readily available carbohydrates in the rumen has also been proposed (Beever and Reynolds, 1994) and several studies comparing the source of carbohydrate as well as protein degradability in the concentrate on $\mathrm{N}$ excretion have been undertaken (Castillo, 1999). Valk and Hobbelink (1992) reported several experiments designed to examine the effect on $\mathrm{N}$ utilisation of replacing high fertilised herbage by low-protein and high energy feeds, including maize silage and concentrates. Total faecal excretion was estimated by $\mathrm{Cr}_{2} \mathrm{O}_{3}$ and urinary $\mathrm{N}$ excretion as the difference between total $\mathrm{N}$ intake and $\mathrm{N}$ output in faeces and milk. The authors concluded that partial replacement of high $\mathrm{N}$ herbage with feedstuffs containing high energy and low protein reduced urinary $\mathrm{N}$ excretion. Moreover, concentrate mixtures based on digestible fibre or starch increased $\mathrm{N}$ output in milk, whilst a smaller response was observed with maize silage. According to these studies, fibre-based supplements tended to increase faecal $\mathrm{N}$ excretion compared with starch-based concentrates. However, MacGregor et al. (1983) with iso-nitrogenous and high concentrate diets (40:60, forage:concentrate), found no effect on $\mathrm{N}$ excretion in faeces or urine when replacing ground maize grain in the concentrate with a high fibre source (hominy feed). Gonda et al. (1996) in two studies also decreased NDF intake whilst increasing starch intake, and found that $\mathrm{N}$ balance was unaffected by the treatments, but milk protein concentration was significantly increased on the starch diets. Similar results were obtained by Keady et al. (1998), in which starch content was increased from 50 to $384 \mathrm{~g} / \mathrm{kg}$ DM but no effects on total $\mathrm{N}$ excretion in urine or faeces were observed.

For most cereal grains, at least $90 \%$ of the starch is normally digested in the rumen, possible exceptions being maize and sorghum where $30 \%$ or so of ingested starch can escape ruminal fermentation, largely to be digested in the small intestine (Ørskov, 1986; Sauvant et al., 1994). However, information comparing different starch sources, with respect to the effect of starch availability in the rumen or the small intestine on $\mathrm{N}$ balance in dairy cattle is limited. Petit and Tremblay (1995) working with supplements containing different energy and protein sources and grass silage diets, concluded that high maize when compared with barley diets, could lead to increased fermentation of non-structural carbohydrates in the caecum, which could stimulate microbial protein synthesis and, hence, increase faecal $\mathrm{N}$ output at the expense of urinary $\mathrm{N}$ excretion. Mason (1969) working with sheep suggested this would decrease urinary nitrogen excretion by increased flux of urea from blood to the large intestine, there to be used by the microbial popula- 
tion in the caecum and ultimately voided as faecal $\mathrm{N}$. This was confirmed by Castillo (1999) who compared iso-nitrogenous diets with barley or maize-based concentrates and found that urinary $\mathrm{N}$ excretion was significantly higher in cows fed high degradable starch (barley).

Better defined trends have been observed when evaluating the effect of different protein sources on $\mathrm{N}$ excretion. By increasing $\mathrm{N}$ availability in the rumen directly as urea (Susmel et al., 1995; Lines and Weiss, 1996) or increasing the $\mathrm{N}$ content in grass silage through different fertilisation levels (Peyraud and Astigarraga, 1998), or increasing the ratio of grass to maize silage in the diet (Valk and Hobbelink, 1992; Metcalf et al., 1996; Smits et al., 1997), N excretion as urine was systematically increased with generally negligible effects on faecal and milk $\mathrm{N}$ output. In diets with high proportions of rumen degradable protein or an excess of rumen undegradable protein, or both, a substantial proportion of this $\mathrm{N}$ will normally be excreted in urine. Castillo (1999) established a significant negative linear relationship between relative (reduced) rumen degradability of protein and urinary $\mathrm{N}$ excretion.

\section{An analysis of nitrogen balance data}

Data from 91 diets fed to 580 dairy cows in trials carried out in different countries has been collated and used to analyse $\mathrm{N}$ utilisation in dairy cows. The data with respect to $\mathrm{N}$ output in urine, faeces and milk in relation to $\mathrm{N}$ intake is illustrated in Figure 1. Nitrogen intake ranged from approximately 200 to $750 \mathrm{~g} / \mathrm{d}$, equivalent to 1.1 to $4.7 \mathrm{~kg} \mathrm{CP} / \mathrm{d}$. The data included a wide range of feeding situations, from dairy cows supplemented with purified protein-free feed and receiving almost $400 \mathrm{~g} \mathrm{urea} / \mathrm{head} / \mathrm{d}$ as the sole source of $\mathrm{N}$ (Kreula and Ettala, 1977), to cows overfed with $\mathrm{N}$ on high quality pastures or supplemented with high protein concentrate feeds and consuming more than $4 \mathrm{~kg} \mathrm{CP} / \mathrm{d}$ (Valk and Hobbling, 1992; Wright et al., 1998) (Appendix).

Both faecal $\left(\mathrm{N}_{\mathrm{f}}\right)$ and milk $\mathrm{N}\left(\mathrm{N}_{\mathrm{rm}}\right)$ output were linearly related to $\mathrm{N}$ intake $\left(\mathrm{N}_{\mathrm{i}}\right)$ while an exponential increase in urinary $\mathrm{N}\left(\mathrm{N}_{u}\right)$ output as $\mathrm{N}$ intake increased was observed (Figure 1) and these are summarised as follows:

$$
\begin{array}{ll}
\mathrm{N}_{\mathrm{f}}=0.21\left(\mathrm{~N}_{\mathrm{i}}\right)+52.3 & \mathrm{R}^{2}=0.48 \\
\mathrm{~N}_{\mathrm{m}}=0.17\left(\mathrm{~N}_{\mathrm{i}}\right)+41 & \mathrm{R}^{2}=0.42 \\
\mathrm{~N}_{\mathrm{u}}=30.4\left(\mathrm{e}^{0.0036 \mathrm{Ni}}\right) & \mathrm{R}^{2}=0.76
\end{array}
$$

From this large database, it is evident that urine appears to be the main route of $\mathrm{N}$ excretion in dairy cows, especially at $\mathrm{N}$ intakes greater than $400 \mathrm{~g} / \mathrm{d}$ (approximately equivalent to $3-3.5 \mathrm{~g} \mathrm{~N} / \mathrm{kg}^{75}$ per day), a level of feeding which suggests that further levels of $\mathrm{N}$ supplementation will be used for milk synthesis with very 
low overall efficiency in average yielding dairy cows. Thus, in cows managed on typical dairy diets a substantial proportion of total $\mathrm{N}$ excretion is as urine, which is in agreement with previous reports (Tamminga, 1992; Peyraud et al., 1995; Bockmann et al., 1996). However, studies with high genetic merit dairy cows (over $10000 \mathrm{~kg}$ milk/lactation) have suggested that the efficiency of $\mathrm{N}$ utilisation and specifically the output of $\mathrm{N}$ in faeces and urine (Beever et al., 1998; Cammell, S.B. personal communication, 1999), could differ from the data presented in Figure 1, which is largely representative of dairy cows from average yielding herds.

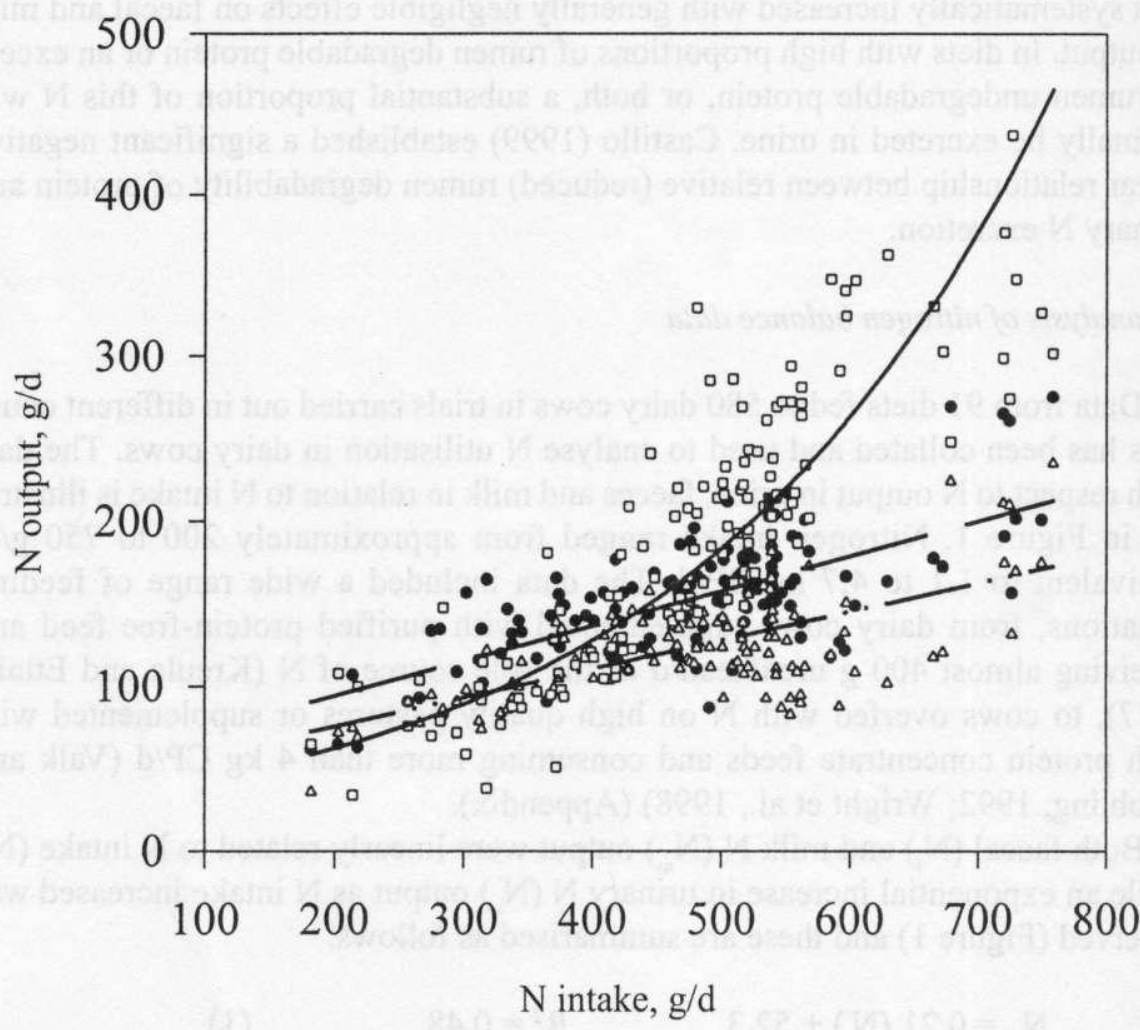

Figure 1. Relationship between total nitrogen intake and output in faeces $(\bullet)$, urine $(\square)$ and milk $(\Delta)$. The fitted lines were given by equations $1(--), 2(\ldots \ldots .$.$) and 3(-)$

Coefficients for the estimated efficiencies of conversion of dietary $\mathrm{N}$ to faecal $\left(\mathrm{N}_{\mathrm{fi}}\right)$, milk $\left(\mathrm{N}_{\mathrm{mi}}\right)$ and urinary $\mathrm{N}\left(\mathrm{N}_{\mathrm{ui}}\right)$ are shown in Figure 2, and the mathematical expressions presented below: 


$$
\begin{array}{ll}
\mathrm{N}_{\mathrm{fi}}=-0.0003\left(\mathrm{~N}_{\mathrm{i}}\right)+0.46 & \mathrm{R}^{2}=0.25 \\
\mathrm{~N}_{\mathrm{ui}}=0.2\left(\mathrm{e}^{0.012 \mathrm{Ni}}\right) & \mathrm{R}^{2}=0.28 \\
\mathrm{~N}_{\text {mi }}=-0.0002\left(\mathrm{~N}_{\mathrm{i}}\right)+0.36 & \mathrm{R}^{2}=0.21
\end{array}
$$

The strength of the relationships was weak possibly due to the nature of the datasets used but the trends are quite clear. As expected, as $\mathrm{N}$ intake increased, the proportion of dietary $\mathrm{N}$ converted into milk or faecal $\mathrm{N}$ declined, and both were represented by linear relationships (Figure 2) such that $\mathrm{N}$ was converted to faeces at a rate of $0.40 \mathrm{~g} / \mathrm{g} \mathrm{N}$ intake when cows consumed $200 \mathrm{~g} / \mathrm{d}$ decreasing to $0.25 \mathrm{~g} / \mathrm{g} \mathrm{N}$ intake when cows ate $750 \mathrm{~g} / \mathrm{d}$. Within the same range of $\mathrm{N}$ intake, efficiency of $\mathrm{N}$ conversion to milk declined from 0.32 to $0.21 \mathrm{~g} / \mathrm{g}$, suggesting that an increase in $\mathrm{N}$ intake of $300 \mathrm{~g} / \mathrm{d}$ (from $400-700 \mathrm{~g} / \mathrm{d}$ ) will increase milk $\mathrm{N}$ output by only $42 \mathrm{~g} / \mathrm{d}$. In contrast, conversion of dietary $\mathrm{N}$ to urine $\mathrm{N}$ increased exponentially as $\mathrm{N}$ intake increased. In part this will be related to the failure of the rumen microbial population to utilise the extra $\mathrm{N}$ with the primary route of removing excess ammonia from the rumen being conversion to urea in the liver after absorption, followed by excretion in urine (Van Soest, 1994). As a result, an increase in $\mathrm{N}$ intake from 400 to $700 \mathrm{gN} / \mathrm{d}$ can be predicted from equation 2 to increase urinary $\mathrm{N}$ output by $250 \mathrm{~g} / \mathrm{d}$.

\section{Quantitative analysis of nitrogen balance data from dairy farms}

Dairy farms are seen as potentially major sources of $\mathrm{N}$ emissions (Peel et al., 1997). However, according to Van Der Meer and Van Der Putten (1995), there is little published information about nutrient balance on dairy farms. An analysis of $\mathrm{N}$ balances from available information on dairy farms published in different EU countries was compared following the methodology presented by Jarvis et al. (1996). Nitrogen surplus ( $\mathrm{kg} \mathrm{N} / \mathrm{ha} /$ year) was estimated as the difference between total $\mathrm{N}$ input (as $\mathrm{N}$ derived from fertilisers, soil and atmosphere $\mathrm{N}_{2}$ fixation, and concentrate feeds) and $\mathrm{N}$ output (as $\mathrm{N}$ in milk, meat, wool, gains and the losses by leaching, denitrification and volatilisation). The efficiency of $\mathrm{N}$ secretion in milk has also been considered and expressed in relation to total $\mathrm{N}$ input. The results are presented in Table 1, which includes traditional dairy systems with high inputs of nitrogen (HIN) and extensive systems with low inputs (LIN) of nitrogen fertilisers.

The average $\mathrm{N}$ input in HIN was $433 \mathrm{~kg} \mathrm{~N} / \mathrm{ha} / \mathrm{y}$ with almost $90 \%$ of this being derived from fertilisers and concentrates. These values are close to those reported by Peel et al. (1997), which indicated total $\mathrm{N}$ input in the UK to be between $300-400 \mathrm{~kg} \mathrm{~N} / \mathrm{ha}$. The global average efficiency was $65 \%$ and represents an excess (soil retention) of $160 \mathrm{~kg} \mathrm{~N} / \mathrm{ha} / \mathrm{y}$ (total input - total output). The average efficiency of $\mathrm{N}$ retention in milk in high input $\mathrm{N}$ dairy systems is low and can 


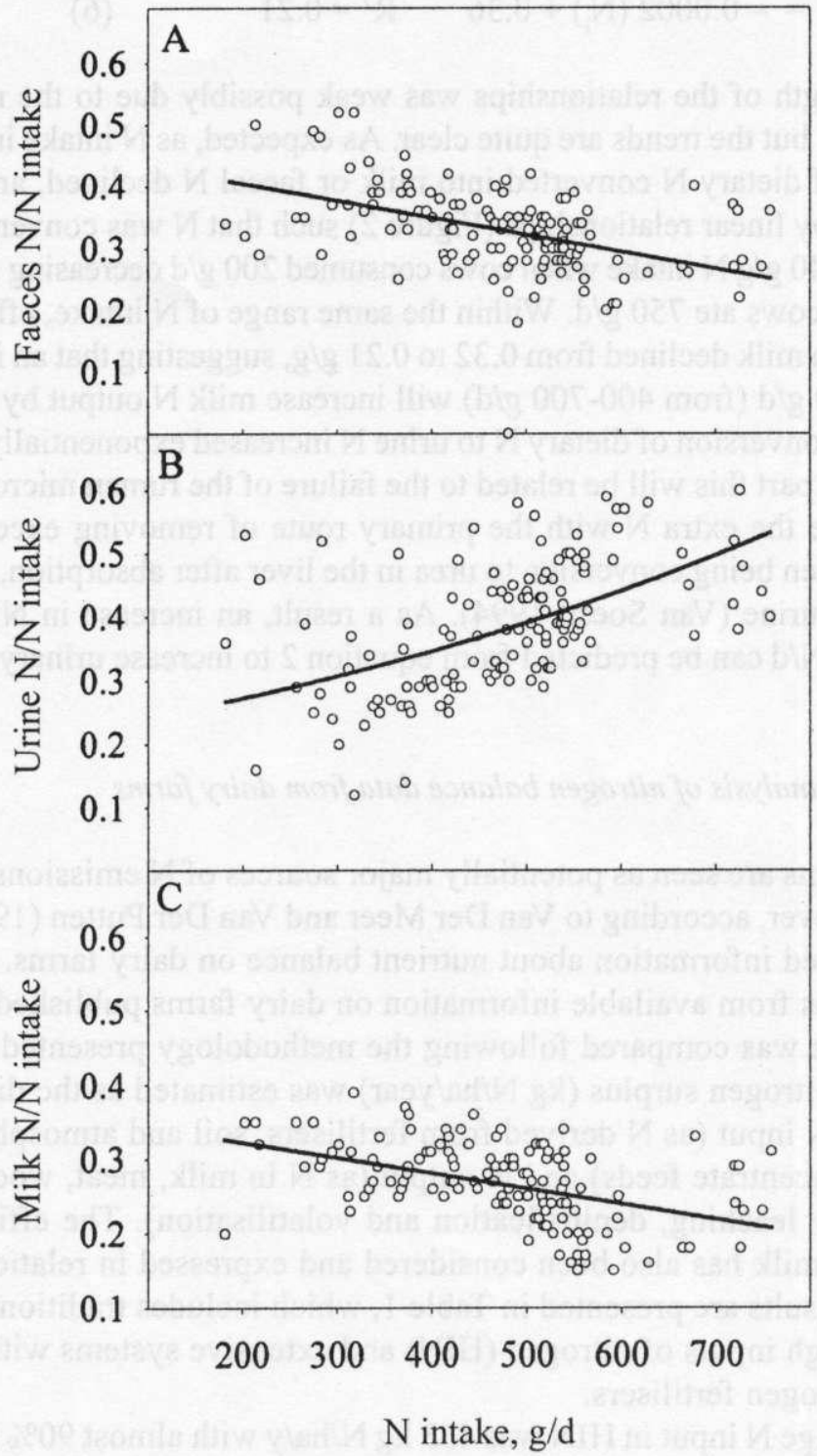

Figure 2. Relationship between total nitrogen intake and output in faeces, urine and milk expressed as a proportion of nitrogen intake. The fitted lines are given by equations 4 to 6 for faecal, urinary and milk $\mathrm{N}$, respectively 
fluctuate between 0.12 for a very intensive dairy farms in the Netherlands (Aarts et al., 1992; Korevaar, 1992) to 0.26 under grazing conditions in New Zealand (Ledgard et al., 1998).

The measures to improve $\mathrm{N}$ utilisation at the farm level should include: (a) reduced and/or tactical use of $\mathrm{N}$ fertilisation, (b) slurry injection, (c) replacement of fertilisers by white clover and (d) inclusion of forage maize in the rotations. A simple evaluation of the impact of these practices is presented in Table I (LIN), where an average three-fold reduction in $\mathrm{N}$ fertilisation and $40 \%$ reduction in concentrate $\mathrm{N}$ intake reduced overall $\mathrm{N}$ input by more than $50 \%$ resulting in a $30 \%$ reduction in milk $\mathrm{N}$ output but a $60 \%$ reduction in $\mathrm{N}$ losses by leaching, denitrification and volatilisation. The input of $75 \mathrm{~kg} \mathrm{~N} / \mathrm{ha}$ in LIN was similar to the mean of $85 \mathrm{~kg} \mathrm{~N} /$ ha reported for 121 French dairy farms with low N inputs (Simon et al., 1994). Global efficiency was similar between HIN and LIN (0.65 and 0.67, respectively), but the efficiency of $\mathrm{N}$ utilisation for milk production increased by

TABLE 1

Comparison of $\mathrm{N}$ inputs and outputs between high versus low nitrogen fertiliser use in dairy systems, $\mathrm{kgN} / \mathrm{ha} /$ year

\begin{tabular}{|c|c|c|c|c|c|c|}
\hline & \multicolumn{3}{|c|}{ High nitrogen input } & \multicolumn{3}{|c|}{ Low nitrogen input } \\
\hline & average & & range & average & & range \\
\hline \multicolumn{7}{|l|}{ Input } \\
\hline fertilizer & 296 & 215 & -413 & 75 & 0 & -185 \\
\hline atmosphere & 27 & 2 & $-\quad 48$ & 24 & 2 & -40 \\
\hline fixation & 30 & 0 & -117 & 65 & 7 & -174 \\
\hline concentrates & 73 & 3 & -173 & 43 & 3 & -52 \\
\hline total input & 433 & 337 & -564 & 207 & 138 & -269 \\
\hline \multicolumn{7}{|l|}{ Output } \\
\hline milk & 75 & 62 & -92 & 53 & 21 & 75 \\
\hline meat, wool, gains, etc. & & & & 33 & 1 & 63 \\
\hline leaching & 80 & 55 & -152 & 26 & 14 & 43 \\
\hline denitrification & 39 & 17 & $-\quad 55$ & 23 & 5 & 44 \\
\hline volatilisation & 45 & 33 & -65 & 21 & 6 & $-\quad 34$ \\
\hline total output & 273 & 223 & -368 & 136 & 109 & -176 \\
\hline Total oulput/N input & 0.65 & 0.44 & 0.80 & 0.67 & 0.52 & 0.84 \\
\hline Milk N/total $N$ input $\S$ & 0.18 & 0.12 & $-\quad 0.26$ & 0.27 & 0.08 & $-\quad 0.42$ \\
\hline Balance & 160 & 89 & -317 & 71 & 23 & -108 \\
\hline
\end{tabular}

data from Germon and Couton (1989), Aarts et al. (1992), Weissbach and Ernst (1994), Van der Meer and Van der Putten (1995), Jarvis et al. (1996), Donaghy et al. (1997) and Ledgard et al. (1998).

$\S$ the value in low nitrogen input includes meat, wool, etc. 
$50 \%$ with an important reduction in $\mathrm{N}$ retention in the soil of $90 \mathrm{~kg} / \mathrm{ha} / \mathrm{y}$. Kohn et al. (1997) reported similar data with a $40 \%$ reduction in $\mathrm{N}$ losses in relation to product output and a $48 \%$ increase in total farm $\mathrm{N}$ efficiency due to improvements in the nutritional efficiency of the herd.

\section{NITROGEN OUTPUT AND ENVIRONMENTAL IMPACT}

The results of this study suggest that substantial changes in the amount and form of $\mathrm{N}$ excretion will result when increased levels of $\mathrm{N}$ are fed to dairy cows. A predicted intake of $400 \mathrm{~g} \mathrm{~N} / \mathrm{d}$ seems to be the critical point in relation to the form in which $\mathrm{N}$ is excreted (Castillo et al., 1999). At $\mathrm{N}$ intake levels below $400 \mathrm{~g} / \mathrm{d}$, faeces is the principal route of $\mathrm{N}$ output, but urinary $\mathrm{N}$ undoubtedly becomes the major route of $\mathrm{N}$ excretion at dietary $\mathrm{N}$ intakes above this level. It can be estimated that a $\mathrm{N}$ intake of $400 \mathrm{~g} / \mathrm{d}$ is quite representative of the levels of $\mathrm{N}$ consumed by typical dairy cows producing around $20-25 \mathrm{~kg}$ of milk/d in an average lactation (AFRC, 1993).

Nitrogen excreted in urine and faeces affects the environment in different ways. With respect to air pollution, Lockyer and Whitehead (1990) reported that volatilisation of ammonia from urinary $\mathrm{N}$ was at least 5-6 times higher than from faecal N. In the soil, Pakrou and Dillon (1995) reported that $24 \%$ of urine N leached to below a depth of $150 \mathrm{~mm}$ in non-irrigated field with the remaining urinary $\mathrm{N}$ in the soil converted from urea to ammonium within a day. Because the form in which $\mathrm{N}$ is excreted appears to be important in terms of environmental pollution, a further analysis was undertaken to investigate the changes that occur in the pattern of $\mathrm{N}$ excretion above and below $400 \mathrm{~g} \mathrm{~N}$ intake/d (Figure 3, equations 7-12). With respect to $\mathrm{N}$ intake between approximately 200 to $400 \mathrm{~g} / \mathrm{d}$, the relationships between $\mathrm{N}$ intake and faecal, urinary and milk $\mathrm{N}$ outputs can be best expressed as follows:

$$
\begin{array}{ll}
\mathrm{N}_{f}=0.38\left(\mathrm{~N}_{\mathrm{i}}\right. & \mathrm{R}^{2}=0.5 \\
\mathrm{~N}_{\mathrm{u}}=0.21\left(\mathrm{~N}_{\mathrm{i}}\right)+29.3 & \mathrm{R}^{2}=0.16 \\
\mathrm{~N}_{\mathrm{m} 1}=0.23\left(\mathrm{~N}_{\mathrm{i}}\right)+5.8 & \mathrm{R}^{2}=0.61
\end{array}
$$

Kirchgessner et al. (1991) reported values for 153 dairy cows consuming 220 to $430 \mathrm{~g} \mathrm{~N} / \mathrm{d}$ of 0.39 and $0.32\left(\mathrm{~N}_{\mathrm{j}}\right)$ for faeces and urine, respectively, which were similar to values obtained when the above data were reanalysed excluding this specific dataset $(0.37$ and 0.29 for faeces and urine, respectively, assuming the origin as the intercept).

With $\mathrm{N}$ intakes above $400 \mathrm{~g} / \mathrm{d}$, the relationships as presented in Figure 3 were as follows: 


$$
\begin{array}{ll}
\mathrm{N}_{\mathrm{f}}=0.23\left(\mathrm{~N}_{\mathrm{i}}\right)+41 & \mathrm{R}^{2}=0.33 \\
\mathrm{~N}_{\mathrm{u}}=0.67\left(\mathrm{~N}_{\mathrm{i}}\right)-132.7 & \mathrm{R}^{2}=0.63 \\
\mathrm{~N}_{\mathrm{m}}=0.14\left(\mathrm{~N}_{\mathrm{i}}\right)+56.6 & \mathrm{R}^{2}=0.17
\end{array}
$$

Thus rates of increase for faecal and milk $\mathrm{N}$ at $\mathrm{N}$ intakes above $400 \mathrm{~g} / \mathrm{d}$ were much lower than those derived for lower $\mathrm{N}$ intakes while urine $\mathrm{N}$ was highly affected by the increased level of $\mathrm{N}$ intake. This information could be important in defining strategies to re-direct $\mathrm{N}$ excretion as faeces or urine and in attempts to rationalise $\mathrm{N}$ utilisation in lactating dairy cows using improved feeding models. In areas with $\mathrm{N}$ pollution problems, $400 \mathrm{~g} \mathrm{~N} / \mathrm{d}$, which in dietary $\mathrm{CP}$ terms represents approximately $150 \mathrm{~g} \mathrm{CP} / \mathrm{kg} \mathrm{DM}$, should be considered as an upper limit of $\mathrm{N}$ intake for commercial dairy farms.

To analyse the overall environmental impact of $\mathrm{N}$ pollution by dairy cows, it is necessary to determine the actual quantities of $\mathrm{N}$ excreted from typical dairy farms. The relationship between total $\mathrm{N}$ intake and output as faeces, urine and milk is shown in Figure 4A. For the information used in this study, a significant correlation was obtained between $\mathrm{N}$ input and output; with $98 \%$ of $\mathrm{N}$ intake recovered in faeces, urine and milk. In theory, changes in body weight are not expected in $\mathrm{N}$ balance studies because the animals are normally after the peak of lactation or at an early stage of pregnancy.

A significant correlation between $\mathrm{N}$ intake and $\mathrm{N}$ output was also obtained when only faeces and urine output were considered (Figure 4B), with a substantial inefficiency of $\mathrm{N}$ use in lactating dairy cows being observed in a range of feeding situations and milk production levels. On average, about $72 \%$ of $\mathrm{N}$ intake was excreted in urine and faeces, with an average of $25 \%$ recovered in milk $\mathrm{N}$ (a single line was fitted to the entire data set shown in Figure 4B) and the equation for the best fit is given by $\mathrm{N}$ excreted $=0.72\left(\mathrm{~N}\right.$ intake; $\left.\mathrm{R}^{2}=0.91\right)$. Therefore, from a nutritional point of view, it appears that one of the most important ways to reduce the environmental impact of $\mathrm{N}$ from dairy cattle is by reducing total $\mathrm{N}$ intake. The efficiency of converting dietary $\mathrm{N}$ to milk $\mathrm{N}$ obtained in this study is intermediate compared to previous reports in the literature. Kirchgessner et al. (1994) and Bequette et al. (1998) estimated that overall utilisation of dietary $\mathrm{N}$ for milk synthesis rarely exceeds 0.30 over a whole lactation. On grass silage and whole crop wheat based diets, efficiency of dietary $\mathrm{N}$ conversion to milk $N$ was about 0.29 (Sutton et al., 1998a,b) which increased to 0.32 when a part of the grass silage was replaced with maize silage (Cammell et al., 1999). Sutton et al. (1998a) reported milk conversion rates of up to 0.23 in cows fed urea treated whole crop wheat whilst Wilkerson et al. (1997) with low producing dairy cows, and Bruchem et al. (1991) concluded that the efficiency of dietary $\mathrm{N}$ utilisation in European dairy cattle was no higher than 0.20 and still declining. 


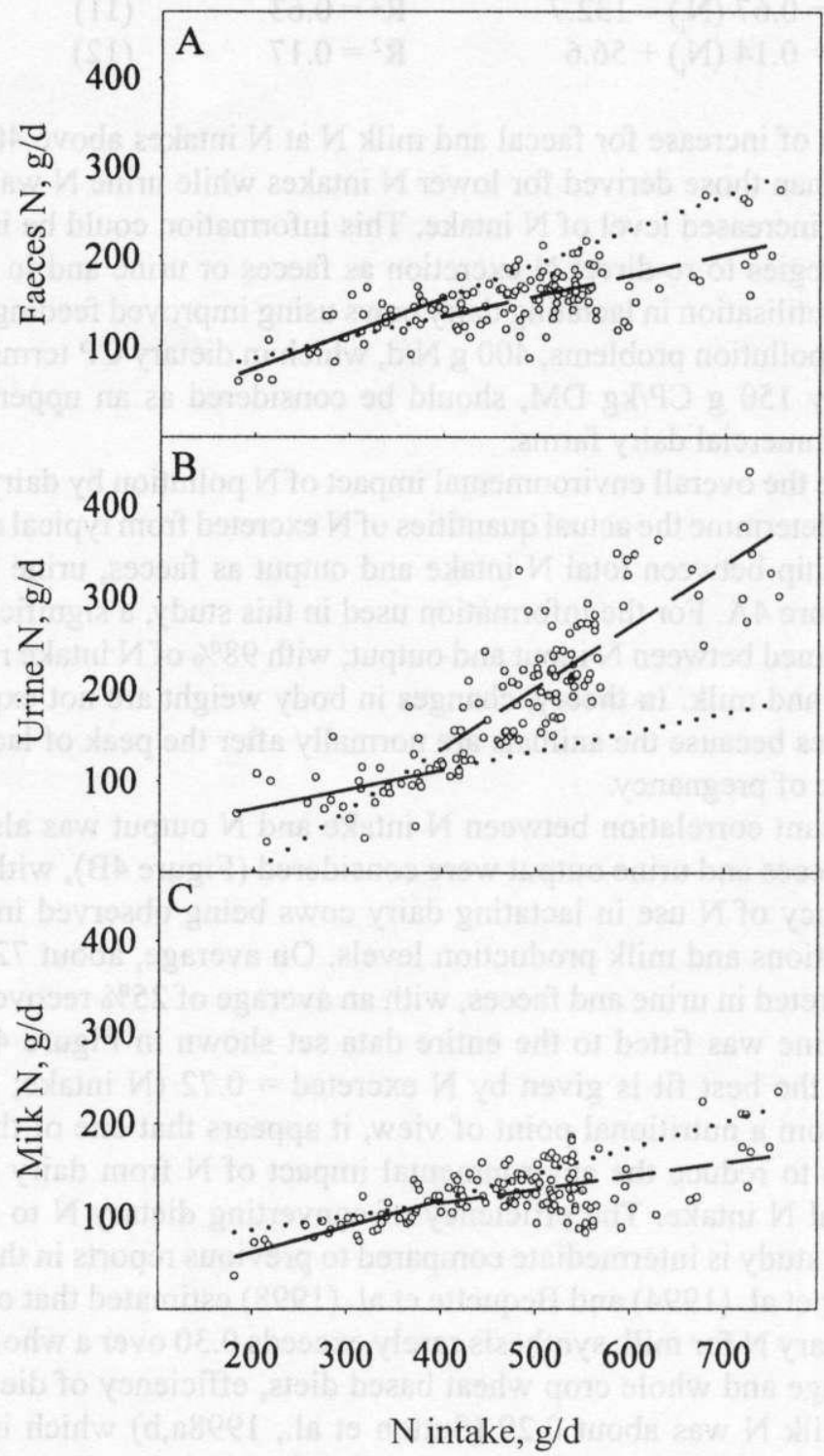

Figure 3. Relationship between $\mathrm{N}$ intake and output in (A) faeces, (B) urine and (C) milk in lactating dairy cows at below and above $400 \mathrm{~g} / \mathrm{d}$ nitrogen intake. Symbols represent data from Appendix. The fitted lines are given by equations (A) 7 (solid lines), 10 (broken line), (B) 8 (solid lines), 11 (broken line) and (C) 9 (solid lines), 12 (broken line) for faeces, urine and milk, respectively. The dotted lines show extrapolations of their respective lines 


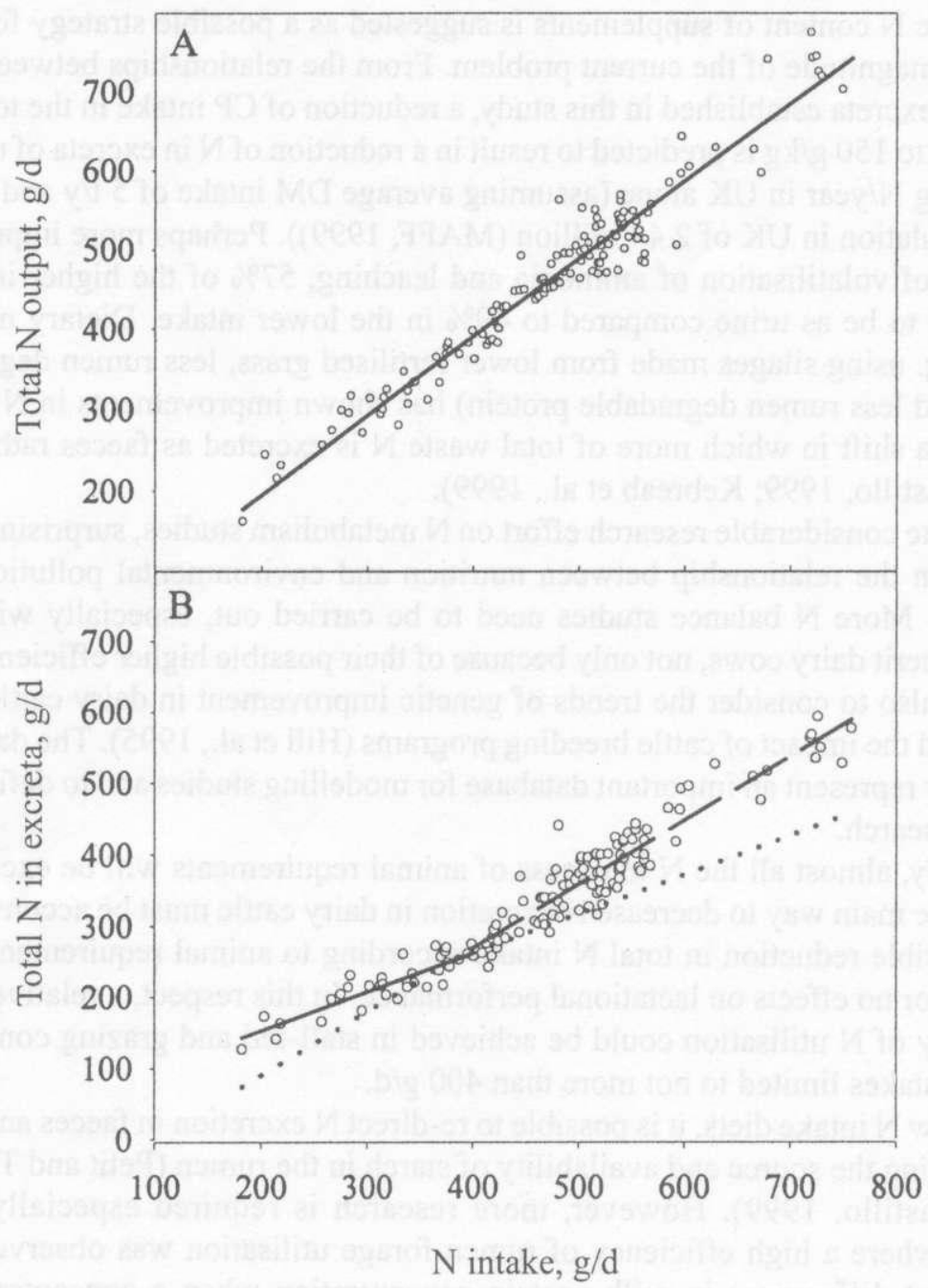

Figure 4. Relationship between $\mathrm{N}$ intake (NI) and total nitrogen output as faeces, urine and milk $\left(\mathrm{N}_{\text {out }}\right)(A)$; and excreted in faeces and urine alone $\left(\mathrm{N}_{\mathrm{Exc}}\right)(\mathrm{B})$. Symbols were experimental data (Appendix). The derived equations are given by $(A) \mathrm{N}_{\text {out }}=0.98(\mathrm{NI}),\left(\mathrm{R}^{2}=0.94\right),(\mathrm{B}) \mathrm{N}_{\text {exc }}=0.55(\mathrm{NI})+$ $43\left(\mathrm{R}^{2}=0.78\right)$ (solid line); and $\mathrm{N}_{\mathrm{exc}}=0.90(\mathrm{NI})-89\left(\mathrm{R}^{2}=0.87\right)$ (broken line). The dotted lines show extrapolations of their respective lines 


\section{CONCLUSIONS}

In respect to the contribution of dairy cows to environmental pollution, reduction in the $\mathrm{N}$ content of supplements is suggested as a possible strategy for reducing the magnitude of the current problem. From the relationships between $\mathrm{N}$ intake and excreta established in this study, a reduction of CP intake in the total diet from 200 to $150 \mathrm{~g} / \mathrm{kg}$ is predicted to result in a reduction of $\mathrm{N}$ in excreta of up to 70 million $\mathrm{kg} \mathrm{N} /$ year in UK alone (assuming average DM intake of $5 \mathrm{t} / \mathrm{y}$ and a dairy cow population in UK of 2.44 million (MAFF, 1999)). Perhaps more importantly in terms of volatilisation of ammonia and leaching, $57 \%$ of the higher intake is predicted to be as urine compared to $49 \%$ in the lower intake. Dietary management (e.g. using silages made from lower fertilised grass, less rumen degradable starch and less rumen degradable protein) has shown improvements in $\mathrm{N}$ utilisation and a shift in which more of total waste $\mathrm{N}$ is excreted as faeces rather than urine (Castillo, 1999; Kebreab et al., 1999).

Despite considerable research effort on $\mathrm{N}$ metabolism studies, surprisingly few studies on the relationship between nutrition and environmental pollution have occurred. More $\mathrm{N}$ balance studies need to be carried out, especially with high genetic merit dairy cows, not only because of their possible higher efficiency of $\mathrm{N}$ use, but also to consider the trends of genetic improvement in dairy cattle in the world and the impact of cattle breeding programs (Hill et al., 1995). The data from this study represent an important database for modelling studies and to define such future research.

Clearly, almost all the $\mathrm{N}$ in excess of animal requirements will be excreted in urine. The main way to decrease $\mathrm{N}$ excretion in dairy cattle must be accomplished by a sensible reduction in total $\mathrm{N}$ intake according to animal requirements, with minimal or no effects on lactational performance. In this respect, a relatively high efficiency of $\mathrm{N}$ utilisation could be achieved in stall-fed and grazing conditions, with $\mathrm{N}$ intakes limited to not more than $400 \mathrm{~g} / \mathrm{d}$.

On low $\mathrm{N}$ intake diets, it is possible to re-direct $\mathrm{N}$ excretion in faeces and urine, by changing the source and availability of starch in the rumen (Petit and Trembly, 1995; Castillo, 1999). However, more research is required especially under grazing where a high efficiency of rumen forage utilisation was observed, with significant differences in milk protein concentration when a concentrate with different energy sources were used (Castillo, 1999).

According to the results of this review and those of Santos et al. (1998), more attention must be given to the use of low rumen degradable protein concentrates, especially when considering pollution problems. To quote Thomas (1998) “... there are economic pressures to supplement forage with extra protein and, as the UK has learned to its cost, when the additional protein is of animal origin, the relationship between the $\mathrm{N}$ cycle and human affairs takes on a new and sinister dimension". 


\section{REFERENCES}

Aarts H.F.M., Biewinga E.E., Van Keulen H., 1992. Dairy farming systems based on efficient nutrient management. Neth. J. Agr. Sci. 40, 285-299

AFRC, 1993. Energy and Protein Requirements for Ruminants. An Advisory Manual Prepared by the AFRC Technical Committee on Responses to Nutrients. CAB International, Wallingford (UK)

AFRC, 1999. Response in the yield of milk constituents to the intake of nutrients by dairy cows. Report No.11 CAB International, Wallingford (UK)

Alderman G., Blake J.S., 1995. The energy and protein requirements according to AFRC (1993) of high genetic merit dairy cows. In: T.L.J. Lawrence, F.J. Gordon, A. Carson (Editors). Breeding and Feeding the High Genetic Merit Dairy Cow. Occasional Publication, Brit. Soc. Anim. Sci. No. 19. Edinburgh (UK), pp. 99-101

ARC, 1980. The Nutrient Requirement of Ruminant Livestock. Technical Review by an Agricultural Research Council Working Party. Commonwealth Agricultural Burcau, Farnham Royal (UK)

ARC, 1984. The Nutrient Requirement of Ruminant Livestock. Supplement No.1. Report of the Protein Group of the ARC Working Party. Commonwealth Agricultural Bureau, Farnham Royal (UK)

Asman W.A., Sutton M.A., Schjørring J.K., 1998. Ammonia: emission, atmospheric transport and deposition. New Phytol. 139, 27-48

Astigarraga L., Peyraud J.L., Le Bars M., 1994. Effect of level of nitrogen fertilization and protein supplementation on herbage utilisation by grazing dairy cows. IJ. Faecal and urine nitrogen excretion. Ann. Zootech. 43, 292 (Abstr.)

Aston K., Thomas C., Daley S.R., Sutton J.D., 1994. Milk production from grass silage diets: effects of the composition of supplementary concentrates. Anim. Prod. 59, 335-344

Beever D.E., 1993. Rumen function. In: J.M. Forbes, J. France (Editors). Quantitative Aspects of Ruminant Digestion and Metabolism. CAB International, Wallingford (UK), pp. 187-215

Beever D.E., Cammell S.B., Sutton J.D., Rowe N., Perrott G.E., 1998. Energy metabolism in high yielding cows. Proc. Brit. Soc. Anim. Sci. 13

Beever D.E., Cammell S.B., Sutton J.D., Spooner M.C., 1989. Effect of concentrate type on energy utilisation in lactating dairy cows. In: Energy Metabolism of Farm Animals. European Association for Animal Production, Publication No.43. Pudoc, Wageningen (The Netherlands), pp. 33-36

Beever D.E., Gill M., 1990. The effect of fishmeal on the digestion of grass silage by growing cattle. Brit. J. Nutr. 63, 489-502

Beever D.E., Reynolds C.K., 1994. Forage quality, feeding value and animal performance. In: J. Frane, L. 't Mannetje (Editors). Grassland and Society. Proceedings of 15th General Meeting European Grassland Federation, Wageningen (The Netherlands), pp. 48-60

Beever D.E., Siddons R.C., 1986. Digestion and metabolism in the grazing ruminants. In: L.P. Milligan, W.L. Grovum, A.D. Englewood (Editors). Ruminant Physiology. Proceedings of 6th International Symposium, NJ (USA), pp. 479-497

Belibasakis N.G., Tsirgogianni D., 1996. The effects of dried citrus pulp on milk yield, milk composition and blood components of dairy cows. Anim. Feed Sci. Tech. 60, 87-92

Bequette B.J., Backwell F.R.C., Crompton L.A., 1998. Current concepts of amino acid and protein metabolism in the mammary gland of the lactating ruminant. J. Dairy Sci. 81, 2540-2559

Bockmann H.C., Junge W., Kalm E., 1996. Eine Methode zur Messung der Stickstoff-Einzeltierbilanzen von Milchkühen unter praktischen Laufstallbedingungen. Arch. Tierzucht 4, $361-368$ 
Broderick G.A., 1992. Relative value of fishmeal versus solvent soybean meal for lactating dairy cows fed alfalfa silage as sole forage. J. Dairy Sci. 75, 174-183

Bruchem J.B., Bosh M.W., Oosting S.J., 1991. Nitrogen efticiency of grassland-based dairy farming - New perspectives using an integrated approach. In: G.E. Groen, J.V. Bruchem (Editors). Utilisation of Local Feed Resources by Dairy Catte. EAAP Publications No 84, Wageningen Press, Wageningen (The Netherlands), pp. 99-101.

Butler W.R., 1997. Review: Effect of protein nutrition on ovarian and uterine physiology in dairy cattle. J. Dairy Sci. 81, 2533-2539

Cadorniga C., Satter L.D., 1993. Protein versus energy supplementation of high alfalfa silage diets for early lactation cows. J. Dairy Sci. 76, 1972-1977

Cammell S.B., Sutton J.D., Bcever D.E., Humphries D.J., Phipps R.H., 1999. The effect of crop maturity on the nutritional value of maize silage for lactating dairy cows. I. Energy and nitrogen utilisation. Submitted

Castillo A.R., 1999. Improving nitrogen utilisation in dairy cows. PhD Thesis, The University of Reading (UK)

Dawson J.M., Bruce C.I., Buttery P.J., Gill M., Beever D.E., 1988. Protein metabolism in the rumen of silage-fed steers: effect of fishmeal supplementation. Brit. J. Nutr. 60, 339-353

Delagarde R., Peyraud, J.L. Delaby L., 1997. The effect of nitrogen fertilization level and protein supplementation on herbage intake. Anim. Feed Sci. Tech. 66, 165-180.

DePeters E.J., Ferguson J.D., 1992. Non-protein nitrogen and protein distribution in the milk of cows. J. Dairy Sci. 75, 3192-3209

Dhiman T.R., Cadorniga C., Satter L.D., 1993. Protein and energy supplementation of high alfalfa silage diets during early lactation. J. Dairy Sci. 76, 1945-1959

Dhiman T.R., Kanneganti V.R., Satter L.D., Walgenbach R.P., Massingill L.J., 1997. Supplementation of roasted soybeans to dairy cows on pasture. Research Summaries. US Dairy Research Forage Center. Wisconsin (USA)

Dhiman T.R., Satter L.D., 1993. Protein as the first limiting nutrient for lactating dairy cows fed high proportions of good quality alfalfa silage. J. Dairy Sci. 76, 1960-1971

Dijkstra, J., France J., Davies D.R., 1998. Different mathematical approaches to estimating microbial protein supply in ruminants. J. Dairy Sci. 81, 3370-3384

Donaghy D., Warman K., Jarvis S.C., Goulding K., Conway J., Hillam J., 1997. Nitrogen flows in mixed farming systems. In: Brit. Grassland Soc. Fifth Research Conference. University of Plymouth (UK), pp. 23-24

Ferguson J.D., Chalupa W., 1989. Impact of protein nutrition on reproduction in dairy cows. J. Dairy Sci. $72,746-758$

Fox D.G., Sniffen C.J., O'Connor J.D., Russell J.B., Van Soest P.J., 1992. A net carbohydrate and protein system for evaluating cattle diets: III. Cattle requirements and diet adequacy. J. Anim. Sci. 70, 3578-3596

Germon J.C., Couton Y., 1989. Nitrogen balance and gaseous nitrogen tosses in soils. In: J.C. Germon (Editor). Managcment Systems to Reduce the Impacts of Nitrates. Elsevier Applied Science, London (UK), pp. 16-31

Gonda H.L., Emanuelson M., Murphy M., 1996. The effect of roughage to concentrate ratio in the diet on nitrogen and purine metabolism in dairy cows. Anim. Feed Sci. Tech. 64, 27-42

Henderson A.R., Garnsworthy P.C., Newbold J.R., Buttery P.J., 1998. The effect of asynchronous diets on the function of the rumen in the lactating dairy cows. Proc. Brit. Soc. Anim. Sci. 19

Henning P.H., Steyn D.G., Meissner H.H.. 1993. Effect of synchronization of energy and nitrogen supply on ruminal characteristics and microbial growth. J. Anim. Sci, 71, 2516-2528 
Hermansen J.E., Ostersen S., Justesen N.C., Aaes O., 1999. Effects of dietary protein supply on caseins, whey proteins, proteolysis and renneting properties in the milk from dairy cows grazing clover or N fertilized grass. J. Dairy Res. 66, 193-205

Herrera-Saldana R., Gomez-Alarcon R., Torabi M., Huber J.T., 1990. Influence of synchronizing protein and starch degradation in the rumen on nutrient utilisation and microbial protein synthesis. J. Dairy Sci. 73, 142-148

Herrera-Saldana R., Huber J.T., 1989. Influence of varying protein and starch degradabilities on performance of lactating cows. J. Dairy Sci. 72, 1477-1483

Hibbitt K.G., 1988. Effect of protein on the health of dairy cows. In: W. Haresing, D.J.A. Cole (Editors). Recent Developments in Ruminants Nutrition 2. Nottingham University Press, Nottingham (UK), pp. 184-185

Hill W.G., Brotherstone S., Visscher P.M. 1995. Current and future developments in dairy cattle breeding: a research viewpiont. In: T.L.J. Lawrence, F.J. Gordon, A. Carson (Editors). Breeding and Feeding the High Genetic Merit Dairy Cow. Occasional Publication, Brit. Soc. Anim. Sci. No. 19. Edinburgh (UK), pp. 1-7

Hongerhold D.D., Muller L.D., 1998. Supplementation of rumen-undegradable protein to the diets of early lactation Holstein cows on grass pasture. J. Dairy Sci. 81, 2204-2214

Hoover W.H., Stokes S.R., 1991. Balancing carbohydrates and proteins for optimum rumen microbial yield. J. Dairy Sci. 74, 3630-3644

Horne D., Muir D.D., 1990. Alcohol and heat stability of milk protein. J. Dairy Sci. 73, 36133626

Huntington G.B., 1997. Starch utilisation by ruminants: from basic to the bunk. J. Anim. Sci. 75 . $852-867$

INRA, 1978. Alimentation des Ruminants. INRA Publications, Versailles (France)

INRA, 1988. Alimentation des Bovins, Ovins et Caprins. INRA, Paris (France)

Jarvis S.C., 1994. The pollution potential and flows of nitrogen to waters and atmosphere from grassland under grazing. In: I. Ap Dewi, R.F.E. Axford, M. Fayez, M. Marai, H.M. Omed (Editors.). Pollution in Livestock Production Systems. CAB International, Wallingford (UK), pp. 227-239

Jarvis S.C., Wilkins R.J., Pain B.F., 1996. Opportunities for reducing the environmental impact of dairy farming managements: a systems approach. Grass Forage Sci. 51, 21-31

Kalscheur K.F., Vandersall J.H., Erdman R.A., Kohn R.A., Russek-Cohen E., 1999. Effects of dietary crude protein concentration and degradability on milk production responses of early, mid and late lactation dairy cows. J. Dairy Sci. 82, 545-554

Keady T.W.J., Maine C.S., Marsden M., 1998. The effects of concentrate energy source on silage intake and animal performance with lactating dairy cows offered a range of grass silages. Anim. Sci. 66, 21-33

Keady T.W.J., Murphy J.J., 1998. The effects of ensiling and supplementation with sucrose and fishmeal on forage intake and milk production of lactating dairy cows. Anim. Sci. 66, 9-20

Kebreab K., Castillo A.R., Beever D.E., Humphries D.J., France J., 1999. Effects of management practices prior to and during ensiling and concentrate type on nitrogen utilisation in dairy cows. J. Dairy Sci. (submitted)

Kirchgessner M., Windisch W., Kreuzer M., 1991. Stickstoffemmission laktierender Milchkühe über die Gülle in Abhängigkeit von der Liestungsintensität. Agribiol.Res. 44, 1-13

Kirchgessner M., Windisch W., Roth F.X., 1994. The efficiency of nitrogen conversion in animal nutrition. Nova Acta Leopoldina 70, 393-412

Kohn R.A., Dou Z., Ferguson J.D., Boston R.C., 1997. A sensitivity analysis of nitrogen losses from dairy farms. J. Environ. Manage. 50, 417-428 
Kolver E., Muller L.D., Varga G.A., Cassidy T.A., 1998. Synchronization of ruminal degradation of supplemental carbohydrates with pasture nitrogen in lactation dairy cows. J. Dairy Sci. 81, 2017-2028

Korevaar H., 1992. The nitrogen balance on intensive Dutch dairy farm: a review. Livest. Prod. Sci. $31,17-27$

Korevaar H., Den Boer D.J., 1990. Practical measures to reduce nutrient losses from grassland systems. Proc. Fertil. Soc. 4-30

Kreula M., Ettala T., 1977. Digestibility and nitrogen balance of the feed of dairy cows with urea as sole or partial source of nitrogen. J. Sci. Agr. Soc. Finland 49, 192-198

Kristensen V.F., Kristensen T., Aaes O., Hansen O.K., 1998. The amount and composition of cattle faeces and urine and excretion of N, $P$ and $K$ in faeces and urine. In: H.D. Poulsen, V.F. Kristensen (Editors.). A Renovation of the Danish Standard Values Concerning the Nitrogen, Phosphorus and Potassium Content of Manure. Danish Institute of Agricultural Science, Ministry of Food, Agriculture and Fisheries, pp. 108-141

Leaver J.D., 1985. Milk production from grazed temperate grassland (Review Article). J. Dairy Res. 52, 313-344

Ledgard S.F., Crush J.R., Penno J.W., 1998. Environmental impacts of different nitrogen inputs on dairy farms and implications for the Resource Management Act of New Zealand. Environ. Pollution 102(S1), 515-519

Lines L.W., Weiss P.W., 1996. Use of nitrogen from ammoniated alfalfa hay, urea, soybean meal and animal protein meal by lactating cows. J. Dairy Sci. 79, 1992-1999

Lockyer D.R., Whitehead D.C., 1990. Volatilization of ammonia from cattle urine applied to grassland. Soil Biol. Biochem. 22, 1137-1142

Macgregor C.A., Stokes M.R., Hoover W.H., Leonard H.A., Junkins L.L., Sniffen C.J., Mailman R.W., 1983. Effect of dietary concentration of total nonstructural carbohydrate and energy and nitrogen metabolism and milk production of dairy cows. J. Dairy Sci. $66,39-50$

MAFF, 1999. Agricultural and Horticultural Census: 1 June, 1988, United Kingdom. Government Statistical Service, York (UK)

MAFF Environment, 1994. Organic manures and nitrate lcaching. In: Solving the Nitrate Problem Progress in Research and Development. MAFF Environment, 11-14

Mason V.C., 1969. Some observations on the distribution and origin of nitrogen in sheep facces. J. Agr. Sci. 73, 99-111

Meijs J.A.C., 1986. Concentrate supplementation of grazing dairy cows. 2. Effect of concentrate composition on herbage intake and milk production. Grass Forage Sci, 41, 229-235

Mertens D.R., Ely L.O., 1979. A dynamic model of fiber digestion and passage in the ruminant for evaluating forage quality. J. Anim. Sci. 54, 895-905

Metcalf J.A., Mansbridge R.J., Blake J.S., 1996. Potential for increasing the efficiency on nitrogen and phosphorus use in lactating dairy cows. Proc. Brit. Soc. Anim. Sci. 62

Morard V., 1999. Emissions of biogenic greenhouse gases from agriculture: political background and a European perspective. In: Biogenic Emissions of Greenhouse Gases Caused by Arable and Animal Agriculture - Processes, Inventories, Mitigation. Institute of Energy Economics and the Rational Use of Energy, University of Stuttgart (Germany), (Abstr.)

Muck R.E., Stcenhuis T.S., 1982. Nitrogen losses from manure storages. Agr. Wastes 4, 41-54

National Research Council, 1989. Nutrient Requirement for Dairy Cattle. 6th Edition. National Academy of Science, Washington, DC

Newbold J.R., Rust S.R., 1992. Effect of asynchronous nitrogen and energy supply on growth of ruminal bacteria in bath culture. J. Anim. Sci. 70, 538-546 
Nocek J.E., Tamminga S., 1991. Site of digestion of starch in gastrointestinal tract of dairy cows and its effects on milk yield and composition. J. Dairy Sci. 74, 3598-3629

$\emptyset$ rskov E.R., 1986. Starch digestion and utilisation in ruminants. J. Dairy Sci. 63, 1624-1633

Pakrou N., Dillon P., 1995. Preferential flow, nitrogen transformations and ${ }^{15} \mathrm{~N}$ balance under urineaffected areas of irrigated and non-irrigated clover-based pastures. J. Contam. Hydrol. 20, 329-347

Peel S., Chambers B.J., Harrison R., Jarvis S.C., 1997. Reducing nitrogen emissions from complete dairy farm systems. In: S.C. Jarvis, B.F. Pain (Editors). Gascous Nitrogen Emissions from Grassland. CAB International, Wallingford (UK), pp. 383-390

Petit H.L., Tremblay G.F., 1995. Ruminal fermentation and digestion in lactating cows fed grass silage with protein and energy supplements. J. Dairy Sci. 78, 342-352

Peyraud J.L., Astigarraga L., 1998. Review of the effects of nitrogen fertilisation on the chemical composition, intake, digestion and nutritive value of fresh forage: consequences on animal nutrition and $\mathrm{N}$ balance. Anim. Feed Sci. Tech. 72, 235-259

Peyraud J.L., Astigarraga L., Faverdin P., 1997. Digestion of fresh perennial ryegrass fertilized at two levels of nitrogen by lactating dairy cows. Anim. Feed Sci. Tech. 64, 155-171

Peyraud J.L., Verité R., Delaby L., 1995. Nitrogen excretion by dairy cows: effect of the diet and of the level of production. Fourrages 142, 131-144

Reynolds C.K., Beever D.E., Sutton J.D.. Newbold J.R., 1996. Effects of incremental duodenal starch infusion on milk composition and yield in dairy cows. J. Dairy Sci. 79, Suppl, 1, 138 (Abstr.)

Reynolds C.K., Sutton J.D., Beever D.E., 1997. Effects of feeding starch to dairy cattle on nutrient availability and production. In: P.C. Garnsworthy, J. Wiseman, W. Haresign (Editors). Recent Advances in Animal Nutrition. Nottingham University Press, Nottingham (UK), pp. 105-133

Roffler R.E., Thacker D.L., 1983. Influence of reducing dietary crude protein from 17 to 13.5 percent on early lactation. J. Dairy Sci. 66, 51-58

Santos F.A.P., Santos J.E.P., Theurer C.B., Huber J.T., 1998. Effects of rumen undegradable protein on dairy cows performance: a 12-year literature review. J. Dairy Sci. 81, 3182-3213

Santos J.E.P., Huber J.T., Theurer C.B., Nusio L.G., Tarazon M., Santos F.A.P., 1999. Responses of lactating dairy cows to steam-flaked sorghum, stcam-flaked corn, or steam-rolled corn and protein sources of differing degradability. J. Dairy Sci. 82, 728-737

Sauvant D., Chapoutot P., Archimède H., 1994. Les digestion des amidons par les ruminants et ses consequences. INRA Prod. Anim. 7, 115-124

Shabi Z., Arieli A., Bruckental 1., Aharoni Y., Zamwel S., Bor A., Tagari H., 1998. Effect of the synchronization of the degradation of dietary crude protein and organic matter and feeding frequency on ruminal fermentation and flow of digesta in the abomasum of dairy cows. J. Dairy Sci. 81, 1991-2000

Simon J.S., Corre L., Vertes F., 1994. Nitrogen balances on a farm scale: results from dairy farms in North-West France. In: Procedings of 15 th General Meeting European Grassland Federation, Wageningen (The Netherlands), pp. 429-433

Sinclair L.A., Garnsworthy P.C., Newbold J.R., Buttery P.J., 1993. Effect of synchronizing the rate of dietary energy and nitrogen release on rumen fermentation and microbial protein synthesis in sheep. J. Agr. Sci. 120, 251-263

Sinclair L.A., Garnsworthy P.C., Newbold J.R., Buttery P.J., 1995. Effects of synchronizing the rate of dictary energy and nitrogen release in diets with a similar carbohydrate composition on rumen fermentation and microbial protein synthesis in sheep. J. Agr. Sci. 124, 463-472

Smits M.C.J., Valk H., Elzing A., Keen A., 1995. Effect of protein nutrition on ammonia emission from a cubicle house for dairy cattle. Livest. Prod. Sci. 44, 147-156 
Smits M.C.J., Valk H., Monteny G.J., Van Vuuren A.M., 1997. Effect of protein nutrition on ammonia emission from cow houses. In: S.C. Jarvis, B.F. Pain (Editors). Gaseous Nitrogen Emissions from Grasslands. CAB International, Wallingford (UK), pp. 101-107

Spanghero M., Kowalski Z.M., 1997. Critical analysis of $\mathrm{N}$ balance experiments with lactating cows. Livest. Prod. Sci. 52, 113-122

Susmel P., Spanghero M., Stefanon B., Mills C.R., 1995. Nitrogen balance and partitioning of some nitrogen catabolites in milk and urine of lactating cows. Livest. Prod. Sci. 44, 207-219

Sutton J.D., 1989. Altering milk composition. J. Dairy Sci. 72, 2801-2814

Sutton J.D., Aston K., Beever D.E.. Dhanoa M.S., 1996. Milk production from grass silage diets: effects of high-protein concentrates for lactating heifers and cows on intake, milk production and milk protein fractions. Anim. Sci. 62, 207-215

Sutton J.D., Aston K., Beever D.E., Fisher W.J., 1994. Milk production from grass silage diets: the relative importance of the amount of energy and crude protein in the concentrates. Anim. Prod. 59, 327-334

Sutton J.D., Cammell S.B., Beever D.E., Humphries D.J., Phipps R.H., 1998a. Energy and nitrogen balance of lactating dairy cows given mixtures of urea-treated whole-crop wheat and grass silage. Anim. Sci. 67, 203-212

Sutton J.D., Phipps R.H., Humphries D.J., 1998b. Whole crop wheat for lactating dairy cows II. The effect of crop maturity on digestibility. Report No. 102, CEDAR, The University of Reading (UK)

Tamminga S., 1992. Nutrition management of dairy cows as a contribution to pollution control. J. Dairy Sci. 75, 345-357

Tamminga S., Verstegen M.W.A., 1996. Implications of nutrition of animals on environmenta] pollution. In: P.C. Garnsworthy, W. Haresign, D.J.A. Cole (Editors). Recent Advances in Animal Nutrition. Nottingham University Press, Nottingham (UK), pp. 113-130

Thomas H., 1998. Air today - gone tomorrow? New Phytol. 139, 225-229

Thomas P.C., 1984. Feeding and milk protein production. In: M.E. Castle, R.G. Gunn (Editors). Milk Compositional Quality and its Importance in Future Markets. Occasional Publication, Brit. Soc. Anim. Prod. No 9, 53-68

Ulyatt M.J., 1997. Can protein utilisation from pasture be improved? Proc. New Zealand Soc. Anim. Prod. 57, 4-8

Valk H., Hobbelink M.E.J., 1992. Supplementation of grazing dairy cows to reduce environmental pollution. In: Proceedings of 14th General Meeting European Grassland Federation. Lathi (Finland), pp. 400-405

Valk H., Klein Poelhuis H.W., Wentink H.J., 1990. Effect of fibrous and starchy carbohydrates in concentrates as supplements in herbage-based diet for high-yielding dairy cows. Neth. J. Agr. Sci. 38, 475-486

Van Der Meer H.G., Van Der Putten H.J., 1995. Reduction of nutrient emissions from ruminant livestock farms. In: G.E. Pollott (Editor). Grassland into 21 st Century: Challenges and Opportunities. Occasional Publication, Brit. Grassl. Soc. No 29, Harrogate (UK), pp. 118-134

Van Soest P.J., 1994. Nutritional Ecology of the Ruminant. 2nd Edition. Cornell University Press, Ithaca

Van Soest P.J., Robertson J.B., Lewis B.A., 1991. Methods for dietary fiber, neutral detergent fibre, and nonstarch polysaccharides in relation to animal nutrition. J. Dairy Sci. 74, 35833597

Viets F.G., Hageman R.H., 1971. Factors affecting the accumulation of nitrates in soil, water and plants. Agricultural Research Scrvice. United State Department of Agriculture, Agricuiture Handbook No. 413. Washington, DC 
Weissbach F., Ernst P., 1994. Nutrient budgets and farms management to reduce nutrient emissions. In: J. Frane, L. ' $t$ Mannetje (Editors). Grassland and Society. Proceedings of 15th General Meeting European Grassland Federation. Wageningen (The Netherlands), pp. 343-360

Wilkerson V.A., Mertens D.R., Casper D.P., 1997. Prediction of excretion of manure and nitrogen by Holstein dairy cattle. J. Dairy Sci. 80, 3193-3204

Witt M.W., Sinclair L.A., Wilkinson R.G., Buttery P.J., 1998. Effects of synchronising the hourly release of energy and nitrogen in the rumen on feed intake and production of lactating ewes. Proc. Brit. Soc. Anim. Sci. 21

Witt M.W., Sinclair L.A., Wilkinson R.G., Buttery P.J., 1999. The effects of synchronising the rate of dietary energy and nitrogen supply to the rumen on the production and metabolism of sheep: food characterisation and growth and melabolism of ewe lambs given food ad-libitum. Anim. Sci. 69, 223-235

Wright T.C., Moscardini S., Luimes P.H., Mcbride B.W., 1998. Effects of rumen-undegradable protein and feed intake on nitrogen balance and milk protein production in dairy cows. J. Dairy Sci. 81, 784-793

Yan T., Roberts D.J., Higginbotham J., 1997. The effects of feeding high concentration of molasses and supplementing with nitrogen and unprotected tallow on intake and performance on dairy cows. Anim. Sci. 64, 17-24

\section{STRESZCZENIE}

\section{Przegląd literatury na temat wykorzystania azotu przez krowy mleczne i jego związek z zanie- czyszczeniem środowiska}

Przedstawiony przegląd literatury dotyczy wykorzystania azotu przez krowy mleczne, ze szczególnym uwzględnieniem ich udziału w zanieczyszczeniu powietrza oraz przecieków zanieczysz czeń do rzek i wód gruntowych. Przeprowadzono ilościową analize udziału krów mlecznych w zanieczyszczaniu środowiska na poziomie gospodarstwa i przedyskutowano wpływ dodatków do diet różnego typu węglowodanów i białka. Zależność między pobraniem azotu i jego bilansem badano wykorzystując opublikowane w literaturze dane uzyskane z 90 doświadczeń przeprowadzonych na 580 krowach. Zastosowanie analizy regresji pozwoliło na opisanie zaleźności między pobraniem azotu i jego wydalaniem z kałem i moczem oraz w mleku.

Nieefektywne wykorzystanic azotu przez krowy mleczne wskazuje, że około $72 \%$ pobranego z paszą azotu jest wydalane $z$ kałem i moczem. Stwierdzono dodatnią liniową zależność między pobraniem azotu i jego wydaleniem w kale, moczu i mleku gdy ilość pobranego azotu nic przckraczała $400 \mathrm{~g} \mathrm{~N} / \mathrm{dzień}$. Jednakże wydalanic azotu w moczu przy pobraniu powyżej $400 \mathrm{~g} \mathrm{~N} / \mathrm{dzień} \mathrm{wzrastało}$ wykładniczo, podczas gdy tempo wzrostu wydalania azotu w kale i mleku obniżało się liniowo. W celu zmnicjszenia zanieczyszczeń azotem zaleca się zmniejszenic ilości białka ogólnego w całej diecie do około $150 \mathrm{~g} / \mathrm{kg}$ suchej masy, co może obniżyć wydalanie azotu z kałem w ciagu roku o około $21 \%$, a co ważniejsze - z moczem o $66 \%$. W praktyce żywienia krów kiszonkani należy dobierać takic dodatki, które mogą zmniejszyć ilość wydalanego azotu i dążyć, o ile to możliwe, do zmniejszenia stosunku ilości azotu wydalanego w moczu do ilości azotu wydalanego w kale. 
APPENDIX

Nitrogen balance in dairy cows, $\mathrm{N}$ intake and output in faeces, urine and milk with different diets

\begin{tabular}{|c|c|c|c|c|c|c|c|}
\hline \multirow[b]{2}{*}{ Forages } & \multirow[b]{2}{*}{ Supplements and fertilizers } & \multirow{2}{*}{$\begin{array}{l}\text { Total } \\
\text { cows }\end{array}$} & \multicolumn{4}{|c|}{ Nitrogen } & \multirow[b]{2}{*}{ References } \\
\hline & & & intake & $\begin{array}{c}\text { faeces } \\
\mathrm{g} / \mathrm{d}\end{array}$ & milk & urine & \\
\hline GS & standard suppl. $200 \mathrm{gCP} / \mathrm{kgDM}$ & 4 & 375 & 124 & 108 & 146 & Sutton et al., 1998a \\
\hline 2GS:1WCW40 & standard suppl. $200 \mathrm{gCP} / \mathrm{kgDM}$ & & 448 & 169 & 115 & 166 & \\
\hline IGS:2WCW20 & standard suppl. $200 \mathrm{gCP} / \mathrm{kgDM}$ & & 476 & 188 & 115 & 152 & \\
\hline IGS:2WCW40 & standard suppl. $200 \mathrm{gCP} / \mathrm{kgDM}$ & & 479 & 196 & 114 & 183 & \\
\hline Zero grazing & nil & 63 & 266 & 93 & 78 & 104 & Keady and Murphy, 1998 \\
\hline GS & nil & & 218 & 63 & 69 & 100 & \\
\hline GS+sucrose & sucrose & & 203 & 65 & 72 & 108 & \\
\hline GS+sucrose+fish meal & sucrose+fish meal & & 284 & 83 & 86 & 148 & \\
\hline GS & $50 \mathrm{~g} \mathrm{starch} / \mathrm{kg} \mathrm{DM}$ & 60 & 528 & 159 & 106 & 242 & Keady et al., 1998 \\
\hline GS & $209 \mathrm{~g} \mathrm{starch} / \mathrm{kg} \mathrm{DM}$ & & 521 & 157 & 112 & 243 & \\
\hline GS & $384 \mathrm{~g} \mathrm{starch} / \mathrm{kg} \mathrm{DM}$ & & 543 & 152 & 111 & 269 & \\
\hline Zero grazing & $0 \mathrm{~kg} \mathrm{~N} / \mathrm{ha}$ & 4 & 257 & 91 & 91 & 76 & Peyraud et al., 1997 \\
\hline Zero grazing & $250 \mathrm{~kg} \mathrm{~N} / \mathrm{ha}$ & & 365 & 91 & 93 & 181 & \\
\hline Grazing & $60 \mathrm{~kg} \mathrm{~N} / \mathrm{ha}$ & 9 & 423 & 110 & 109 & 204 & Astigarraga et al., 1994 \\
\hline Grazing & $60 \mathrm{~kg} \mathrm{~N} / \mathrm{ha}+2 \mathrm{~kg}$ soyabean meal & & 594 & 132 & 123 & 340 & \\
\hline Grazing & $300 \mathrm{~kg} \mathrm{~N} / \mathrm{ha}$ & & 503 & 113 & 109 & 281 & \\
\hline Grazing & $0 \mathrm{~kg} \mathrm{~N} / \mathrm{ha}$ & 8 & 315 & 102 & 98 & 115 & Delagarde et al., 1997 \\
\hline Grazing & $0 \mathrm{~kg} \mathrm{~N} / \mathrm{ha}+2 \mathrm{~kg}$ soyabean meal & & 466 & 119 & 125 & 220 & \\
\hline Grazing & $250 \mathrm{~kg} \mathrm{~N} / \mathrm{ha}$ & & 585 & 118 & 119 & 348 & \\
\hline
\end{tabular}


APPENDIX - continue

Nitrogen balance in dairy cows, $\mathrm{N}$ intake and output in faeces, urine and milk with different diets

\begin{tabular}{|c|c|c|c|c|c|c|c|}
\hline \multirow[b]{2}{*}{ Forages } & \multirow[b]{2}{*}{ Supplements and fertilizers } & \multirow{2}{*}{$\begin{array}{l}\text { Total } \\
\text { cows }\end{array}$} & \multicolumn{4}{|c|}{ Nitrogen } & \multirow[b]{2}{*}{ References } \\
\hline & & & intake & $\begin{array}{c}\text { faeces } \\
\mathrm{g} / \mathrm{d}\end{array}$ & milk & urine & \\
\hline Grazing & compound feed & 27 & 726 & 157 & 132 & 437 & Valk and Hobbelink, 1992 \\
\hline Grazing $+\mathrm{CS}$ & nil & & 501 & 151 & 124 & 223 & \\
\hline Grazing $+\mathrm{CS}$ & compound feed & & 537 & 140 & 120 & 214 & \\
\hline Grazing $+\mathrm{CS}$ & compound feed & 28 & 418 & 177 & 139 & 106 & Valk and Hobbelink, 1992 \\
\hline Zero grazing $+\mathrm{CS}$ & compound feed & & 372 & 166 & 139 & $5 \mathrm{I}$ & \\
\hline Zero grazing & concentrate-high fibre (beet pulp) & & 376 & 150 & 135 & 98 & \\
\hline Zero grazing & concentrate-high starch (maize) & & 318 & 165 & 122 & 38 & \\
\hline Zero grazing $+\mathrm{CS}$ & compound feed & 27 & 540 & 161 & 141 & 238 & Valk and Hobbelink, 1992 \\
\hline Zero grazing & concentrate-high fibre (beet pulp) & & 491 & 87 & 124 & 285 & \\
\hline Zero grazing & concentrate-high starch (maize) & & 481 & 111 & 123 & 330 & \\
\hline Grazing & compound feed & 35 & 629 & 164 & 102 & 363 & Valk and Hobbelink, 1992 \\
\hline Zero grázing & dry beet pulp & & 554 & 162 & 83 & 272 & \\
\hline Zero grazing & wet beet pulp & & 554 & 149 & 93 & 294 & \\
\hline Zero grazing & $\operatorname{corn}-\operatorname{cob}-\operatorname{mix}$ & & 535 & 162 & 93 & 261 & \\
\hline Zero grazing & maize-ear-ground & & 547 & 157 & 87 & 272 & \\
\hline Grazing & compound feed & 35 & 604 & 149 & 109 & 347 & Valk and Hobbelink, 1992 \\
\hline Zero grazing & dry beet pulp & & 592 & 127 & 88 & 291 & \\
\hline Zero grazing & wet beet pulp & & 562 & 139 & 95 & 281 & \\
\hline Zero grazing & corn-cob-mix & & 562 & 130 & 90 & 264 & \\
\hline Zero grazing & maize-ear-ground & & 562 & 130 & 95 & 271 & \\
\hline GS & suppl. (213 gCP/kgDM) & 6 & 526 & 178 & 124 & 169 & Metcalf et al., 1996 \\
\hline $\mathrm{GS}+\mathrm{CS}$ & suppl. (163 gCP $/ \mathrm{kgDM})$ & & 424 & 157 & 122 & 122 & \\
\hline
\end{tabular}

$\mathrm{GS}+\mathrm{CS}$

suppl. ( $63 \mathrm{gCP} / \mathrm{kgDM}$ ) 
Nitrogen balance in dairy cows, $\mathrm{N}$ intake and output in faeces, urine and milk with different diets

\begin{tabular}{|c|c|c|c|c|c|c|c|}
\hline \multirow[b]{2}{*}{ Forages } & \multirow[b]{2}{*}{ Supplements and fertilizers } & \multirow{2}{*}{$\begin{array}{l}\text { Total } \\
\text { cows }\end{array}$} & \multicolumn{4}{|c|}{ Nitrogen } & \multirow[b]{2}{*}{ References } \\
\hline & & & intake & $\begin{array}{c}\text { faeces } \\
\mathrm{g} / \mathrm{d}\end{array}$ & milk & urine & \\
\hline Fescue hay & compound feed (+urea $0 / \mathrm{kg}$ ) & 8 & 214 & 107 & 75 & 34 & Susmel et al., 1995 \\
\hline Fescue hay & compound feed (turea $20 \mathrm{~g} / \mathrm{kg}$ ) & & 295 & 109 & 91 & 72 & \\
\hline Grazing, CS, GS & compound feed + LF & 19 & 473 & 142 & 161 & 149 & Bockmann et al., 1997 \\
\hline Grazing, CS, GS & compound feed $+\mathrm{HF}$ & 19 & 501 & 141 & 142 & 181 & \\
\hline Luceme hay & suppl. $+1.2 \%$ urea & 15 & 486 & 164 & 145 & 163 & Lines and Wiess, 1996 \\
\hline Lucerne hay & suppl. $+19 \%$ soyabean meal & & 415 & 118 & 143 & 124 & \\
\hline Lucerne hay & suppl. + hay ammoniated & & 418 & 147 & 129 & 111 & \\
\hline Lucerne hay & suppl. + animal protein & & 431 & 160 & 146 & 123 & \\
\hline Silage $40 \%$ & suppl. $60 \%$ high TNSC & 12 & 468 & 159 & 156 & 143 & MacGregor et al., 1983 \\
\hline Silage $40 \%$ & suppl. $60 \%$ low TNSC & & 444 & 144 & 158 & 147 & \\
\hline Feed restriction $20 \%$ & low DUP & 6 & 275 & 134 & 95 & 70 & Wright et al., 1998 \\
\hline Feed restriction $20 \%$ & medium DUP & & 492 & 173 & 112 & 185 & \\
\hline Feed restriction $20 \%$ & high DUP & & 665 & 178 & 118 & 331 & \\
\hline Feed restriction $10 \%$ & low DUP & & 302 & 157 & 98 & 59 & \\
\hline Feed restriction $10 \%$ & medium DUP & & 468 & 186 & 111 & 154 & \\
\hline Feed restriction $10 \%$ & high DUP & & 672 & 173 & 121 & 303 & \\
\hline High forage & low concentr. low fat & 4 & 505 & 183 & 137 & 197 & Gonda et al., 1996 \\
\hline Low forage & high concentr. low fat & & 521 & 182 & 156 & 195 & \\
\hline High forage & low concentr. high fat & & 474 & 157 & 117 & 208 & \\
\hline Low forage & high concentr. high fat & & 497 & 152 & 139 & 214 & \\
\hline
\end{tabular}


Nitrogen balance in dairy cows, $\mathrm{N}$ intake and output in faeces, urine and milk with different diets

GS direct early cut

GS direct early cut

GS early cut wilted

GS early cut wilted

GS direct late cut

GS wilted late cut

GS wilted

GS wilted

GS wilted

GS wilted

GS wilted

$\mathrm{GS}+\mathrm{NH}_{4}$ tetraformate

GS+bacterial inoculant

GS+organic acids

GS

GS

TMR

Grazing
Supplements and fertilizers

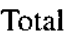

cows

\begin{tabular}{cr} 
& Ni \\
\hline intake & $\begin{array}{r}\text { faece } \\
\mathrm{g} /\end{array}$ \\
182 & 6
\end{tabular}

6

445

540

517

557

481

486

compound feed $+\mathrm{HF}$

compound feed $+\mathrm{HF}$

HF + suppl. starch + fibre

MF + suppl. starch + fibre

LF + suppl. starch + fibre

suppl. starch

suppl. fibre

mix suppl.

mix suppl.

mix suppl.

suppl. barley grain

suppl. maize grain

GS + compound feed

compound feed
$6 \quad 395$

409

345

378

387

6

467

459

482

476

462

$6 \quad 399$

399

518

176

124

122

157

131

133

115

129

$\begin{array}{ll}157 & 135 \\ 163 & 130\end{array}$

167

146

161

138

$154 \quad 122$

urine References

g/d

62

36

129

122

146

I 39

143

165

126

139

$65 \quad$ Kreula and Ettala, 1977

241 Kebreab et al., 1999

214

222

217

205

221

143

118

Kebreab et al., 1999

105

87
94

$\begin{array}{ll}149 & 129 \\ 140 & 116\end{array}$

113

153

130

144

145

154

140

121

ADAS Bridgets, UK

(unpublished)

Kebreab et al., 1999

170 
APPENDIX - continue

Nitrogen balance in dairy cows, $\mathrm{N}$ intake and output in faeces, urine and milk with different diets

\begin{tabular}{|c|c|c|c|c|c|c|c|}
\hline \multirow[b]{2}{*}{ Forages } & \multirow[b]{2}{*}{ Supplements and fertilizers } & \multirow{2}{*}{$\begin{array}{l}\text { Total } \\
\text { cows }\end{array}$} & \multicolumn{3}{|c|}{ Nitrogen } & \multirow[b]{2}{*}{ urine } & \multirow[b]{2}{*}{ References } \\
\hline & & & intake & $\begin{array}{c}\text { faeces } \\
\mathrm{g} / \mathrm{d}\end{array}$ & milk & & \\
\hline GS & nil & 4 & 502 & 177 & 93 & 216 & Petit and Tremblay, 1995 \\
\hline GS & maize grain & & 555 & 191 & 112 & 211 & \\
\hline GS & barley and oat grains & & 543 & 179 & 107 & 216 & \\
\hline GS & sugar beet pulp+soyabean & & 559 & 190 & 109 & 187 & \\
\hline GS & sugar beet pulp+fish meal & & 565 & 201 & 112 & 234 & \\
\hline Grass pellets thay & compound feed & 11 & 374 & 156 & 105 & 108 & Kirchgessner et al., 1991 \\
\hline Grass pellets thay & compound feed & 12 & 334 & 147 & 86 & 114 & \\
\hline Grass pellets+hay & compound feed & 19 & 314 & 135 & 74 & 92 & \\
\hline CS+hay & compound fecd & 34 & 343 & 140 & 100 & 93 & \\
\hline CS+hay & compound feed & 20 & 338 & 126 & 93 & 88 & \\
\hline CS+hay & compound feed & 32 & 329 & 120 & 84 & 77 & \\
\hline CS+hay & compound feed & 25 & 312 & 116 & 79 & 100 & \\
\hline (Total treatments $=91 ;$ & total cows $=580$ ) & & $\mathrm{N}$ intake & $\mathrm{N}$ faeces & $\mathrm{N}$ milk & $\mathrm{N}$ urine & \\
\hline Average, $g / d$ & & & 454 & 145 & 115 & 181 & \\
\hline Min, g/d & & & 182 & 62 & 36 & 34 & \\
\hline $\operatorname{Max}, \mathrm{g} / \mathrm{d}$ & & & 726 & 201 & 161 & 437 & \\
\hline $\mathrm{N}$ intake/ $\mathrm{N}$ output & & & & 0.32 & 0.25 & 0.40 & \\
\hline
\end{tabular}

